\title{
Trace Metals and Source Identification of Air-Borne Particulate Matter Pollution in A Nigerian Megacity
}

\section{Ezeh GC ${ }^{1 *}$, Obioh IB ${ }^{1}$ and Asubiojo $\mathrm{OI}^{2}$}

${ }^{1}$ Centre for Energy Research and Development (CERD), Obafemi Awolowo University, Ile-lfe Nigeria

${ }^{2}$ Department of Chemistry, Obafemi Awolowo University, lle-Ife Nigeria

\begin{abstract}
Background: The megacity status of Lagos has led to increased pressure on the urban environment especially on air quality. Twelfth decade of serving as Nigeria former capital and currently the economic nerve centre of the country, there is yet no holistic information on source apportionment of atmospheric aerosols in the city. Hence, the study was conducted to provide an understanding of the chemical compositions and source identifications of $\mathrm{PM}_{2.5}$ (aerodynamic diameter, $\left.\mathrm{d}_{\mathrm{ae}} \leq 2.5 \mu \mathrm{m}\right)$ and $\mathrm{PM}_{2.5-10}\left(2.5 \mu \mathrm{m}<\right.$ dae $\left._{10} 10 \mu \mathrm{m}\right)$ particulate matter over Lagos, Nigeria.

Methods: Sampling of $\mathrm{PM}_{2.5}$ (fine) and $\mathrm{PM}_{2.5-10}$ (coarse) were collected on nuclepore polycarbonate filters using a low volume GENT sampler (Schlumberger Model: M250) equipped with double staged stacked filter units. A total of 192 samples were collected (96 of each fraction). Elemental analyses of both fractions were carried out using Particle Induced X-ray Emission (PIXE) while Proton Induced Gamma-ray Emission (PIGE) was also employed to complement for X-ray self-absorption effect among low Z elements by PIXE technique.

Results: Data on twenty-four elements ( $\mathrm{Na}, \mathrm{Mg}, \mathrm{Al}, \mathrm{Si}, \mathrm{P}, \mathrm{S}, \mathrm{Cl}, \mathrm{K}, \mathrm{Ca}, \mathrm{Ti}, \mathrm{V}, \mathrm{Cr}, \mathrm{Mn}, \mathrm{Fe}, \mathrm{Ni}, \mathrm{Cu}, \mathrm{Zn}, \mathrm{Se}, \mathrm{Br}, \mathrm{Rb}, \mathrm{Sr}$, $\mathrm{Zr}, \mathrm{Cs}$ and $\mathrm{Pb}$ ) detected in both particulate sizes were displayed, discussed. Receptor modelling of the data for source apportionment and identification were achieved for both fractions via positive matrix factorization (PMF). Five source categories with stable profiles were identified in both fractions.

Conclusions: The study concluded that anthropogenic emissions from gasoline oil combustions, industrial, and biomass burning emissions were more predominant and could pose great hazard to Lagos receptors during the sampling period.
\end{abstract}

Keywords: Source apportionment; PIXE; Positive matrix factorization; Emissions

\section{Introduction}

Lagos $\left(6.45^{\circ} \mathrm{N}\right.$ and $\left.3.39^{\circ} \mathrm{E}\right)$ is the former capital of Nigeria. It is also the industrial and commercial nerve center accounting for over $40 \%$ of the industries in Nigeria. Lagos is also a coastal city with relatively small land mass $\left(3577 \mathrm{~km}^{2}\right)$ and population density of about 2400 persons per $\mathrm{km}^{2}[1]$. The city is also the hub of the nation's aviation activities as it handles about $74 \%$ international departures and $37 \%$ domestic connections [2]. It is therefore obvious that most inhabitants of Lagos could face serious environmental pollution challenges especially on air pollution; owing to the fact that her high population density and associated anthropogenic activities could impact much pressure on the relatively small land mass. As typical of a sub Saharan tropical city, Lagos climate is seasonally damp and very humid. Its climate is influenced by monsoons originating from South Atlantic Ocean and brought by maritime tropical air mass, a warm moist sea to land seasonal wind. Lagos temperature is almost constant throughout the year and averaged to $26^{\circ} \mathrm{C}$. The annual rainfall received in Lagos is very high, usually above $4000 \mathrm{~mm}$ of rainfall [2] and with two distinct seasons; Harmattan (October, November, December, January and February) while the rest of the months are in Rain Season.

A number of urban areas across Nigeria are known to experience elevated levels of atmospheric particulate matter (APM) pollution [3]. Scientific studies of APM concentrations are needed to understand and regulate the factors that contribute to air quality deterioration. Sourcereceptor relationships for particulate matter could be identified and quantified using a number of techniques such as receptor modeling based on measurements done at receptor site. Few works on receptor model based source apportionment of APM have been reported in Nigeria; [4] applied chemical mass balance (CMB) receptor model on the elemental composition data obtained from Lagos and identified four (entrained dust, marine, regional sulphate and vehicular emissions) sources of APM. Recently [5] identified soil, automobile, marine, residual oil combustion and biomass burning emissions as the major sources of $\mathrm{PM}_{2.5-10}$ in Lagos hot-spots with CMB model. However, these earlier studies had inherent problems of underestimation or overestimation of sources. In addition, few sources were resolved probably due to usage of imported source profiles in the CMB based modeling [6]. Unfortunately, methodologies for source profiles measurements are often cumbersome, time-consuming, and expensive hence, information on local source profiles is largely lacking in Nigeria.

A different but highly effective tool for receptor modelling exists in using positive matrix factorization (PMF) model to apportion sources without the prior knowledge of local emissions source profiles. PMF offers a viable alternative given the absence of a local source profile library for air pollutants especially in most developing countries such as Nigeria. PMF have been applied successfully in the studies of aerosol sources of many cities; Toronto, Canada [7]; Atlanta, USA [8] Pittsburg, USA [9]; Beijing, China [10]; Bangladesh [11] and Costa Rica [12]. An

*Corresponding author: Ezeh GC, Centre for Energy Research and Development (CERD), Obafemi Awolowo University, Ile-Ife Nigeria, Tel: +2348036568835; E-mail: gcezeh@cerd.gov.ng (or) goddyich@yahoo.com

Received March 17, 2017; Accepted April 21, 2017; Published May 03, 2017

Citation: Ezeh GC, Obioh IB, Asubiojo OI (2017) Trace Metals and Source Identification of Air-Borne Particulate Matter Pollution in A Nigerian Megacity. J Environ Anal Toxicol 7: 463. doi: 10.4172/2161-0525.1000463

Copyright: @ 2017 Ezeh GC, et al. This is an open-access article distributed unde the terms of the Creative Commons Attribution License, which permits unrestricted use, distribution, and reproduction in any medium, provided the original author and source are credited. 
Citation: Ezeh GC, Obioh IB, Asubiojo OI (2017) Trace Metals and Source Identification of Air-Borne Particulate Matter Pollution in A Nigerian Megacity. J Environ Anal Toxicol 7: 463. doi: 10.4172/2161-0525.1000463

excellent review of PMF modeling was presented in [6]. PMF have not been applied in the studies of aerosols in Nigeria until recently [13], applied it in their study of occupational exposures of aerosols in a smelting plant. Inadvertently, PMF is yet to be applied for study at receptor sites in Nigeria, hence a key motivation for the work.

Therefore, the focus of this study is to identify natural and anthropogenic sources of $\mathrm{PM}_{25}$ and $\mathrm{PM}_{2510}$ chemical compositions as well as to apportion their contributions by applying PMF receptor model. The data generated from this work will be a key tool in understanding particulate matter sources as well in providing vital information for policy makers in designing effective control strategies.

\section{Materials and Methods}

\section{Description of sampling sites}

Three sampling sites (Figure 1) located at Lagos Nigeria were used for this study due to their reflection of variations in urban infrastructures such as usual high traffic, residential areas and industrial features. These are Ikeja $\left(6^{\circ} 36^{1} 16.76^{11} \mathrm{~N}\right.$ and $\left.3^{\circ} 20^{1} 12.99^{11} \mathrm{E}\right)$, Ikoyi $\left(6^{\circ} 29^{1} 21.17^{11}\right.$ $\mathrm{N}$ and $\left.3^{\circ} 23^{1} 2.45^{11} \mathrm{E}\right)$ and Mushin $\left(6^{\circ} 31^{1} 57.65^{11} \mathrm{~N}\right.$ and $3^{\circ} 20^{1} 58.52^{11}$ E). Ikeja represents a typical industrial and medium residential area, Mushin is a typical high density residential area while Ikoyi is a wellplanned and secluded area exclusively reserved for the opulent class and it represents the low density populated area.

\section{Samplings}

A total of one hundred and ninety-two samples of $\mathrm{PM}_{25}$ and $\mathrm{PM}_{25-10}$ were collected simultaneously in the study sites from July to September 2007 to capture rain season variations effectively. Sampling was achieved using "Gent" stacked filter sampler [14] capable of segregating both size fractions. The samples were collected by gravimetric analysis on pre-weighed and pre-conditioned $8 \mu \mathrm{m}$ (coarse) and $0.4 \mu \mathrm{m}$ (fine) pore sized Whatman polynuclepore filters (supplied by Essque Nigeria Limited, Lagos, Nigeria). Detailed methodology for $\mathrm{PM}_{25}$ and $\mathrm{PM}_{2510}$ sampling using Gent stacked filter sampler have been reported [15]. Mass-balance analyses of the exposed filters were achieved in triplicate measurements using a digital micro-weighing balance (Sartorius, Göttingen, Germany) which was calibrated using the automated isoCAL function in-order to ensure accuracy. $\mathrm{PM}_{10}$ values were the sum of $\mathrm{PM}_{25}$ and $\mathrm{PM}_{2.5-10}$ mass concentrations. The exposed filters were stored in the desiccator before taken to the laboratory for elemental analysis.

\section{Elemental characterization}

Elemental concentration for each sample was energy-analyzed by Particle Induced X-ray Emission (PIXE) at external ion beam analysis (IBA) set-up of $3 \mathrm{MV}$ Tandetron Nuclear Accelerator available at Instituto Nationale di Fisica Nucleare (INFN) Firenze, Italy. Calibration of the PIXE system was performed by irradiating suitable Micrometer thin target standards. X-ray spectra obtained from the PIXE measurements were analyzed with GUPIXWIN" software developed in Guelph University [16] in order to obtain their net peak areas. The elemental concentrations of the aerosol samples were done using the net peak areas obtained from GUPIXWIN ${ }^{\circ}$ and sensitivity curve, i.e. (counts per $\mu \mathrm{C}$ ) per $\left(\mu \mathrm{g} \mathrm{cm}^{-2}\right)$, obtained by the analysis of certified thin elemental standards [17]

\section{Enrichment factor (EF) and pollution indices (PIs)}

To have a first indication on the extent of the contributions of

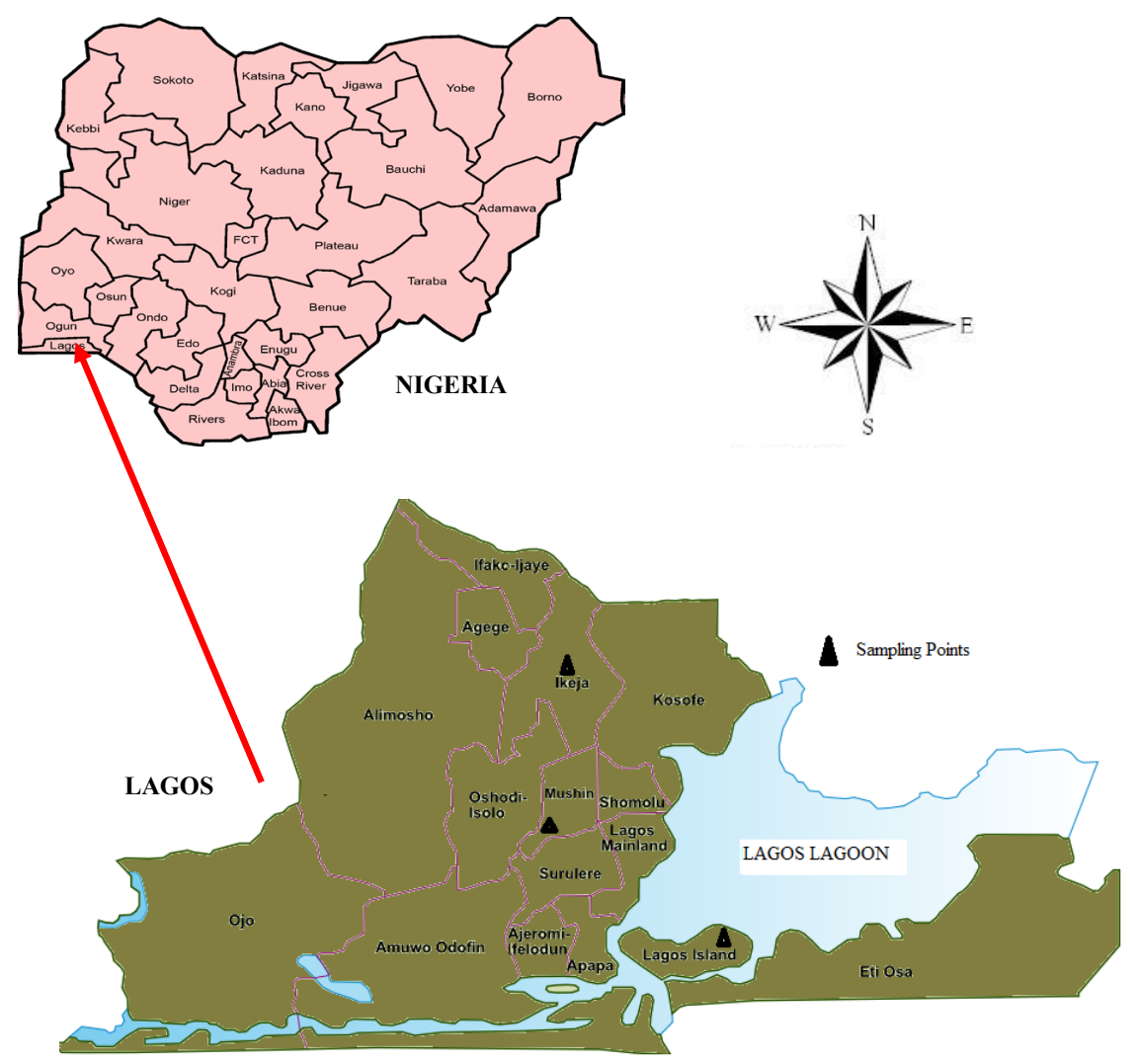

Figure 1: Map of Lagos showing the study sites. 
Citation: Ezeh GC, Obioh IB, Asubiojo OI (2017) Trace Metals and Source Identification of Air-Borne Particulate Matter Pollution in A Nigerian Megacity. J Environ Anal Toxicol 7: 463. doi: 10.4172/2161-0525.1000463

Page 3 of 11

anthropogenic emissions to atmospheric elemental levels, enrichment factors (EF) were calculated for each element using the crustal composition reported elsewhere [18] and $\mathrm{Ti}$ as the normalizing element.

The use of $\mathrm{Ti}$ as a normalizing agent is quite appropriate since, it is a crustal element with little or no anthropogenic influence. Elements with EF next to unity have a strong natural component while elements with high EF could have anthropogenic origin, or are due to other natural sources such as marine aerosols. Pollution indices are also commonly used to assess the environment quality and it is defined as the ratio of element concentration in the study to the background content of the abundance of chemical elements in the continental crust. The PIs of the elements were calculated and classified as either low (PI< $1)$, moderately $(1<\mathrm{PI} \leq 3)$ or high $(\mathrm{PI}>3)$ for both size fraction [19]

\section{Elemental correlation}

The elemental concentrations of the analyzed samples of $\mathrm{PM}_{2.5}$ and $\mathrm{PM}_{2.5-10}$ were subjected to statistical analysis to determine the Pearson distance correlation [20] matrices of the elements. This was calculated using Statistical Package for Social Scientist (SPSS) software and correlation was considered significant at the 0.05 level (two tailed). In order to determine which of the correlations are significant in the statistical sense, the critical multiple correlations coefficient $(r)$ was obtained from the table of significant values. The critical value $r$ with $\mathrm{n}=96$, at $98 \%$ confidence interval, $\mathrm{r}^{2}$ of 1.99 was considered significant.

\section{Source apportionment by Positive Matrix Factorization (PMF)}

The algorithm for PMF model used in the study has been described in detail [21] and implemented in the PMF2 program [22]; therefore, we present a brief description of the model hereafter. PMF receptor model is based on the overlying principle that a relationship between sources and receptors exist when mass conservation is assumed. A conventional factor analysis model can be written as;

$$
Y=X C+E
$$

Where, $\mathrm{Y}$ is a $n \times m$ matrix, with $n$ measurements and $m$ number of elements, $x$ is $n \times p$ source contribution matrix with $p$ sources, $C$ is $p \times m$ source profile matrix and $E$ is $n \times m$ matrix of residuals.

In this case, when chemical speciation of ambient PM is available, a mass balance equation of the following form can be written as:

$$
y_{i j}=\sum_{m=1}^{P} x_{i m} c_{m j}+e_{i j}
$$

Where, $y_{i j}$ is the $j^{\text {th }}$ species concentration measured in $i^{\text {th }}$ sample, $x_{i m}$ is the contribution of the $m^{\text {th }}$ factor to the receptor on the $i^{\text {th }}$ day, $c_{m j}$ is the fraction of the $m^{\text {th }}$ factor that is species $j, e_{i j}$ is the residual for the $j^{\text {th }}$ species on the $i^{\text {th }}$ day and $p$ is the total number of independent sources.

PMF provides a solution that minimizes an object function, Q (E), based upon uncertainties for each observation [24]. This function is defined as;

$$
Q(E)=\sum_{m=1}^{n} \sum_{j=1}^{m}\left(\frac{e_{i j}}{\sigma_{i j}}\right)^{2}
$$

Where $e_{i j}$ is the un-modelled portion and $\sigma i j$ is the standard deviation of the $j^{\text {th }}$ element measured in the $i^{\text {th }}$ sample.
PMF applies non-negative constraint to source profiles and its contributions. It does not allow chemical species with lots of uncertainty to influence the estimation of the contributions and profiles. The uncertainty estimation provides a useful tool to decrease the weight of missing and below detection limits data in the solution; this is a particularly interesting feature when fine fractions with very low elemental concentrations are analyzed. In this work, the widely adopted procedure for data treatment suggested by [23] was used for the treatment of concentrations and the associated uncertainties data which serves input for the PMF model. For improved resolution of sources, the PMF receptor model requires a large matrix of chemical species, source apportionment was performed by combining all the data from the three sites and a data matrix of 96 (samples) $\times 23$ (variables) and 96 (samples) $\times 19$ (variables) were used for $\mathrm{PM}_{25}$ and $\mathrm{PM}_{2.5-10}$ respectively. About $3 \%$ extra modelling uncertainty was applied to all $\mathrm{PM}_{2.5}$ species in order to accommodate errors which were not considered during measurements. This is evidenced in the high missing and below detection limit values observed for most species in the $\mathrm{PM}_{25}$ fraction. Prior to PMF modelling, the species were classified into three groups; strong $(\mathrm{S} / \mathrm{N} \geq 1)$, weak $(0.5>\mathrm{S} / \mathrm{N}<1)$, and bad $(\mathrm{S} /$ $\mathrm{N}<0.5$ ). While there was no down-weighting of good species, species with weak signal-to-noise ratio triples the provided uncertainty while categorizations of "bad" were excluded. Therefore, five elements (Ti, $\mathrm{Se}, \mathrm{Rb}, \mathrm{Zr}$, and $\mathrm{Cs}$ ) were excluded from modelling of $\mathrm{PM}_{25}$ while only Cs was excluded in the $\mathrm{PM}_{2.5-10}$ data. The concentration scatter plots as well as the trend plots among the species were also examined for expected relationships which might indicate their possible sources. To ensure that the appropriate number of factors was chosen, the scaled residuals, ratio of the observed concentrations and the PMF-modeled concentrations were also examined. Detailed methodology on PMF modelling have been reported [23].

\section{Results and Discussions}

\section{Mass concentrations}

Manual gravimetric methods have been widely used as the reference method for particulate matter measurements, hence it was employed in the determination of mass concentrations of $\mathrm{PM}_{2.5}$ and $\mathrm{PM}_{10}$ (aerodynamic diameter, $\mathrm{d}_{\mathrm{ae}} \geq 10$ ) as presented in Figure 2. The lowest and highest mean mass concentrations of $\mathrm{PM}_{2.5}$ stood at $4 \mu \mathrm{g}$ $\mathrm{m}^{-3}$ and $16 \mu \mathrm{g} \mathrm{m}^{-3}$ respectively while $\mathrm{PM}_{10}$ recorded $32 \mu \mathrm{g} \mathrm{m}^{-3}$ (lowest) to $75 \mu \mathrm{g} \mathrm{m}^{-3}$ (highest). Interestingly, $\mathrm{PM}_{25}$ average values were lower than the $24 \mathrm{~h} \mathrm{PM}_{2.5}$ Air Quality Guideline (AQG) value of $25 \mu \mathrm{g} \mathrm{m}^{-3}$ [24]. This could be due to time of sampling, amidst Rain season, when most suspended PM has been precipitated. However, for $\mathrm{PM}_{10}$ fraction, the $24 \mathrm{~h}$ World Health Organization $\mathrm{PM}_{10}$ AQG $\left(50 \mu \mathrm{g} \mathrm{m}^{-3}\right)$ was slightly violated during the sampling period. This is not unexpected as $\mathrm{PM}_{10}$ are usually made of re-entrained dust compared to $\mathrm{PM}_{25}$ which emanates mostly due to anthropogenic contributions. Entrained dust is expected to contribute more to particulate loadings in an environment such as Lagos with many unpaved roads and walkways. PM mass concentrations in this study were similar to those reported for urban sites in Ethiopia [25], Morrocco [26] and Kenya [27].

\section{Trace elements}

Table 1 displayed average concentrations, enrichment factor (EF) and pollution indices (PI) of twenty-four elements ( $\mathrm{Na}, \mathrm{Mg}, \mathrm{Al}, \mathrm{Si}, \mathrm{P}$, $\mathrm{S}, \mathrm{Cl}, \mathrm{K}, \mathrm{Ca}, \mathrm{Ti}, \mathrm{V}, \mathrm{Cr}, \mathrm{Mn}, \mathrm{Fe}, \mathrm{Ni}, \mathrm{Cu}, \mathrm{Zn}, \mathrm{Se}, \mathrm{Br}, \mathrm{Rb}, \mathrm{Sr}, \mathrm{Zr}, \mathrm{Cs}$ and $\mathrm{Pb}$ ) detected in both particulate sizes.

For $\mathrm{PM}_{25}$, average concentrations of $\mathrm{S}\left(100 \mathrm{ng} \mathrm{m}^{-3}\right), \mathrm{Ca}(48 \mathrm{ng}$ $\left.\mathrm{m}^{-3}\right), \mathrm{Si}\left(42 \mathrm{ng} \mathrm{m}^{-3}\right), \mathrm{Cl}\left(36 \mathrm{ng} \mathrm{m}^{-3}\right), \mathrm{K}\left(33 \mathrm{ng} \mathrm{m}^{-3}\right)$ and $\mathrm{Na}\left(30 \mathrm{ng} \mathrm{m}^{-3}\right)$ 
Citation: Ezeh GC, Obioh IB, Asubiojo OI (2017) Trace Metals and Source Identification of Air-Borne Particulate Matter Pollution in A Nigerian Megacity. J Environ Anal Toxicol 7: 463. doi: 10.4172/2161-0525.1000463

Page 4 of 11

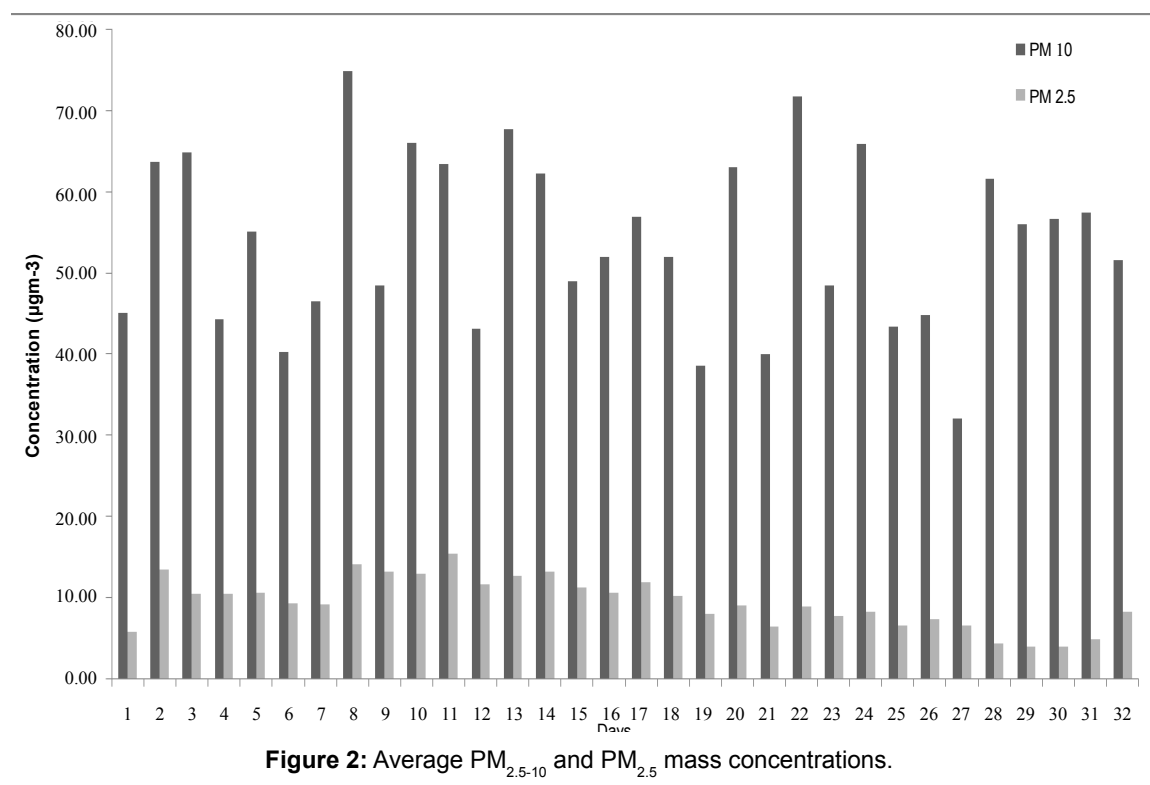

\begin{tabular}{|c|c|c|c|c|c|c|c|}
\hline \multirow{2}{*}{ Elements } & \multirow{2}{*}{$\begin{array}{l}\text { Crustal rock } \\
\text { (Mason, 1966) }\end{array}$} & \multicolumn{2}{|c|}{ Concentration $\left(\mathrm{ngm}^{-3}\right)$} & \multicolumn{2}{|c|}{ Enrichment Factor (EF) } & \multicolumn{2}{|c|}{ Pollution Indices (PIs) } \\
\hline & & $\mathrm{PM}_{2.5-10}$ & $\mathrm{PM}_{2.5}$ & $\mathrm{PM}_{2.5-10}$ & $\mathrm{PM}_{2.5}$ & $\mathrm{PM}_{2.5-10}$ & $\mathrm{PM}_{2.5}$ \\
\hline $\mathrm{Na}$ & 23600 & $819 \pm 11$ & $30 \pm 5$ & 2.54 & 4.11 & 0.03 & 0.00 \\
\hline $\mathrm{Mg}$ & 23300 & $235 \pm 7$ & $11 \pm 4$ & 0.74 & 1.55 & 0.01 & 0.00 \\
\hline $\mathrm{Al}$ & 82300 & $616 \pm 6$ & $15 \pm 3$ & 0.55 & 0.58 & 0.01 & 0.00 \\
\hline $\mathrm{Si}$ & 28150 & $1525 \pm 9$ & $42 \pm 3$ & 3.97 & 4.72 & 0.05 & 0.00 \\
\hline $\mathrm{P}$ & n.d & $20 \pm 4$ & $8 \pm 3$ & n.d & nd & n.d & n.d \\
\hline $\mathrm{S}$ & 260 & $485 \pm 5$ & $100 \pm 3$ & 136.78 & 1225.73 & 1.87 & 0.38 \\
\hline $\mathrm{Cl}$ & 130 & $1095 \pm 8$ & $36 \pm 2$ & 617.02 & 891.90 & 8.42 & 0.28 \\
\hline $\mathrm{K}$ & 20900 & $281 \pm 6$ & $33 \pm 2$ & 0.99 & 5.07 & 0.01 & 0.00 \\
\hline $\mathrm{Ca}$ & 41500 & $1789 \pm 44$ & $48 \pm 10$ & 3.16 & 3.73 & 0.04 & 0.00 \\
\hline $\mathrm{Ti}$ & 5700 & $78 \pm 5$ & $2 \pm 3$ & 1.00 & 1.00 & 0.01 & 0.00 \\
\hline V & 135 & $4 \pm 2$ & $1 \pm 1$ & 1.87 & 22.56 & 0.03 & 0.01 \\
\hline $\mathrm{Cr}$ & 100 & $3 \pm 1$ & $2 \pm 1$ & 1.82 & 54.48 & 0.02 & 0.02 \\
\hline $\mathrm{Mn}$ & 950 & $12 \pm 1$ & $1 \pm 1$ & 0.93 & 3.20 & 0.01 & 0.00 \\
\hline $\mathrm{Fe}$ & 56300 & $640 \pm 7$ & $14 \pm 1$ & 0.83 & 0.80 & 0.01 & 0.00 \\
\hline $\mathrm{Ni}$ & 75 & $2 \pm 0$ & $1 \pm 0$ & 1.70 & 41.92 & 0.02 & 0.01 \\
\hline $\mathrm{Cu}$ & 55 & $5 \pm 0$ & $1 \pm 0$ & 6.74 & 45.88 & 0.09 & 0.01 \\
\hline $\mathrm{Zn}$ & 70 & $42 \pm 1$ & $11 \pm 0$ & 43.95 & 502.46 & 0.60 & 0.16 \\
\hline $\mathrm{Se}$ & 0.05 & $1 \pm 0$ & n.d & 792.16 & n.d & 10.81 & 2.35 \\
\hline $\mathrm{Br}$ & 2.5 & $7 \pm 1$ & $1 \pm 0$ & 198.00 & 1681.49 & 2.70 & 0.53 \\
\hline $\mathrm{Rb}$ & 90 & $3 \pm 1$ & n.d & 2.01 & n.d & 0.03 & 0.00 \\
\hline $\mathrm{Sr}$ & 375 & $7 \pm 1$ & n.d & 1.44 & n.d & 0.02 & 0.00 \\
\hline $\mathrm{Zr}$ & 165 & $3 \pm 1$ & n.d & 1.31 & n.d & 0.02 & 0.00 \\
\hline Cs & n.d & $1 \pm 0$ & $2 \pm 3$ & n.d & n.d & n.d & n.d \\
\hline $\mathrm{Pb}$ & 12.5 & $7 \pm 3$ & $1 \pm 1$ & 43.19 & 241.81 & 0.59 & 0.08 \\
\hline
\end{tabular}

"n d" means "not detected"

Table 1: Average elemental concentrations, enrichment factors and pollution indices of $\mathrm{PM}_{2.5-10}$ and $\mathrm{PM}_{2.5}$ aerosols.

were most pronounced. Sulphur origin in fine particulate could be mainly anthropogenic (energy production, biomass burning, refuse incinerations, emissions from ships using heavy oil). Airborne sulphur rarely occurs as a pure element; it is usually produced as $\mathrm{SO}_{2}$ gas which readily converts to sulphate $\mathrm{SO}_{4}^{2-}$ ions under normal atmospheric conditions. The $\mathrm{SO}_{4}^{2-}$ ions can exist in the atmosphere as sulphuric acid producing acid rain or be partially neutralized to ammonium bisulphate or fully neutralized to ammonium sulphate [28]. Ca and
Si influence in fine fraction could be due to soil dust which is typical of sub-Saharan African aerosol. Interestingly, Ca/Si ratios (1.1) in fine and coarse fractions were the same, indicating similar sources origin. Chlorine $(\mathrm{Cl})$, potassium $(\mathrm{K})$, bromine $(\mathrm{Br})$ and lead $(\mathrm{Pb})$ were found to be major fine fraction components from pyrogenic emissions [29].

Sulphur and Chlorine have also been identified in emissions from savannah grass fires. However, average EF result revealed that $\mathrm{S}, \mathrm{Cl}, \mathrm{Br}$ and $\mathrm{Pb}$ were highly enriched $(\mathrm{EF}>100)$ in both fractions. PIs results of 
Citation: Ezeh GC, Obioh IB, Asubiojo OI (2017) Trace Metals and Source Identification of Air-Borne Particulate Matter Pollution in A Nigerian Megacity. J Environ Anal Toxicol 7: 463. doi: 10.4172/2161-0525.1000463

Page 5 of 11

coarse fraction grouped $\mathrm{S}, \mathrm{Cl}$, and $\mathrm{Br}$ in highly polluted class. Although, average concentrations $\left(1 \mathrm{ng} \mathrm{m}^{-3}\right)$ recorded for Se in coarse particulate is $1 \mathrm{ng} \mathrm{m}^{-3}$ and it is highly enriched. This is evidenced by its high PI (10.81) in coarse fraction. Selenium is found impurely in metal sulphide ores, where it partially replaces sulphur. Hence, its introduction in atmosphere could be from emissions associated to smelting activities, glass factories or from electronic waste due to it usage as semiconductors. Interestingly, $\mathrm{Ni}$ and $\mathrm{Pb}$ average concentrations in fine fraction were lower than European guidelines [30].

For $\mathrm{PM}_{2.5-10}$ fraction, average concentrations of $\mathrm{Al}\left(616 \mathrm{ng} \mathrm{m}^{-3}\right), \mathrm{Si}$ $\left(1525 \mathrm{ng} \mathrm{m}^{-3}\right), \mathrm{Ca}\left(1789 \mathrm{ng} \mathrm{m}^{-3}\right), \mathrm{Fe}\left(640 \mathrm{ng} \mathrm{m}^{-3}\right), \mathrm{Na}\left(819 \mathrm{ng} \mathrm{m}^{-3}\right)$ and $\mathrm{Cl}\left(1095 \mathrm{ng} \mathrm{m}^{-3}\right)$ were dominant. High concentrations of $\mathrm{Na}$ and $\mathrm{Cl}$ were ascribed to sea spray and emissions related to crustal materials. Sea spray emissions are produced when sea becomes supersaturated with hydrocarbon causing a flux from aqueous to gas phase, releasing halogenated organic and inorganic compounds. Imminently, high concentration values recorded for crustal elements ( $\mathrm{Al}, \mathrm{Si}, \mathrm{Ca}$ and $\mathrm{Fe}$ ) could be due to entrained/re-suspended soil dust source. The influence of soil dust is expected in Lagos because most roads and walk-ways are not paved and poorly managed. Though, high concentrations of Ca and $\mathrm{Fe}$ have been linked to anthropogenic activities such as physical construction, quarry, cement factories and metallurgical industrial emissions. PIs revealed low pollution class for crustal elements (Al, $\mathrm{Si}$, $\mathrm{Ca}$ and $\mathrm{Fe}$ ) as their $\mathrm{EF}$ values were $<5$. Due to designation of Lagos as a coastal city, we estimated contributions of sea salt (ss) and nonsea salt (n-ss) components of $\mathrm{Na}, \mathrm{S}, \mathrm{K}$ and $\mathrm{Ca}$ in coarse fraction. The n-ss component of $\mathrm{Na}$ was estimated using crustal $\mathrm{Na} / \mathrm{Al}$ ratio of 0.348 [18]. While, $n$-ss of $S, K$ and Ca were estimated using sea water $\mathrm{S} / \mathrm{Na}(0.084), \mathrm{K} / \mathrm{Na}(0.036)$ and $\mathrm{Ca} / \mathrm{Na}(0.038)$ ratios [31]. From this, concentrations of ss-Na stood at $74 \%$ and $17 \%$ for coarse and fine particulates respectively. While $\mathrm{n}$-ss of S and $\mathrm{K}$ accounted for $96 \%$ and $97 \%$ in coarse fraction respectively. However, sea salt $S$ observed in both fractions was similar to 3\% reported [31]. Conversely, average K/ $\mathrm{Na}(<2)$ and $\mathrm{Ca} / \mathrm{Na}(<3)$ ratios obtained in fine and coarse fractions showed wide disparity from seawater $\mathrm{K} / \mathrm{Na}(0.036)$ and $\mathrm{Ca} / \mathrm{Na}(0.038)$ ratios reported [32]. The wide variation of mass-ratio relative to sodium in both size fractions could be an attestation of multifarious sources of PM in Lagos, been the commercial and industrial nerve center of Nigeria.

\section{Elemental correlations}

The results of elemental Pearson correlations for $\mathrm{PM}_{2.5}$ and $\mathrm{PM}_{2.5-10}$ particulate fractions are presented in Tables 2 and 3 respectively. The elements $\mathrm{Na}$ to $\mathrm{Pb}$ displayed both weak and strong positive as well as negative correlations.

For $\mathrm{PM}_{2.5-10}$ fraction, $\mathrm{Na}$ displayed high positive correlation ( $\mathrm{r}=$ $0.86,0.76,0.95,0.76$ and 0.86 ) with $\mathrm{Mg}, \mathrm{S}, \mathrm{Cl}, \mathrm{K}$ and $\mathrm{Br}$ respectively probably due to their association with soil dust. The $100 \%$ correlation value $(\mathrm{r}=1)$ observed for $\mathrm{Al}$ and $\mathrm{Ti}$ could be a strong indication of similar source origin [33]. Copper displayed strong correlations with many elements; $\mathrm{Mg}(\mathrm{r}=0.87), \mathrm{Al}(\mathrm{r}=0.83), \mathrm{Si}(\mathrm{r}=0.85), \mathrm{P}(\mathrm{r}=0.73), \mathrm{S}$ ( $\mathrm{r}=0.89), \mathrm{K}(\mathrm{r}=0.86), \mathrm{Ca}(\mathrm{r}=0.88), \mathrm{Ti}(\mathrm{r}=0.83), \mathrm{Ti}(\mathrm{r}=0.83), \mathrm{Cr}(\mathrm{r}=0.70)$, $\mathrm{Mn}(\mathrm{r}=0.91), \mathrm{Fe}(\mathrm{r}=0.88), \mathrm{Zn}(\mathrm{r}=0.77), \mathrm{Br}(\mathrm{r}=0.77), \mathrm{Rb}(\mathrm{r}=0.84), \mathrm{Sr}$ $(\mathrm{r}=0.87), \mathrm{Zr}(\mathrm{r}=0.71)$ and $\mathrm{Pb}(\mathrm{r}=0.75)$ thus, it could be linked to multiple sources. For $\mathrm{PM}_{2.5}$ fraction (Table 4), correlation ( $\left.\mathrm{r}=0.57\right)$ registered for $\mathrm{Na}$ and $\mathrm{Cl}$ was not too strong when compared to 0.95 observed in $\mathrm{PM}_{2.5-10}$ fraction probably due to the influence of other anthropogenic sources. The fact that $\mathrm{Al}$ showed negative correlations ( $\mathrm{r}=-0.02)$ with $\mathrm{V}$ revealed different emission source origins. $\mathrm{V}$ showed strong positive correlation with $\mathrm{Ni}(\mathrm{r}=0.98)$, thus confirming their association with emissions from petroleum oil combustion activities. The strong positive correlation $(\mathrm{r}=0.87)$ of $\mathrm{P}$ with $\mathrm{K}$ could indicate similar source origin probably from biomass or waste burning emissions. $\mathrm{Zn}$ correlation with $\mathrm{Mn}(\mathrm{r}=0.78)$ and $\mathrm{Cu}(\mathrm{r}=0.83)$ is appropriate as they could be associated with vehicular or industrial emissions. We also observed positive correlation of $\mathrm{Pb}$ with $\mathrm{S}(\mathrm{r}=0.70)$ and $\mathrm{Br}(\mathrm{r}=0.78)$. Prior to ban in importation of leaded gasoline in Nigeria in 2003, the major source of $\mathrm{Pb}$ in the atmosphere was reported to be mainly from petroleum products consumption [4], hence concentration of $\mathrm{Pb}$ in this fraction could be from local sources. High correlation of $\mathrm{S}$ and $\mathrm{Br}(\mathrm{r}=0.87)$ is quite instructive as the two elements are usually used as additives in petroleum products and most of their compounds are used daily in industries.

\section{Time series}

In order to obtain prior information of variations in elemental concentrations of some known source markers, we plotted time series graphs. Figure $3 \mathrm{a}$ and $3 \mathrm{~b}$ displayed time series graphs obtained for selected $\mathrm{PM}_{2.5-10}$ markers while Figure $3 \mathrm{c}$ and $3 \mathrm{~d}$ represents time series graphs for identified $\mathrm{PM}_{2.5}$ markers.

Time series graph of $\mathrm{Na}$ and $\mathrm{Cl}$ detected in $\mathrm{PM}_{2.5-10}$ fraction are shown in Figure 3a. As expected, both elements (markers for seaspray emissions) portrayed similar time trend even though their concentration values differ. For instance, on $23^{\text {rd }}$ of July 2007, $\mathrm{Na}$ and $\mathrm{Cl}$ concentrations were both registered as $1.3 \mu \mathrm{g} \mathrm{m}^{-3}$. Interestingly, highest concentration of $\mathrm{Na}\left(2 \mu \mathrm{g} \mathrm{m}^{-3}\right)$ and $\mathrm{Cl}\left(3.2 \mu \mathrm{g} \mathrm{m}^{-3}\right)$ occurred on $9^{\text {th }}$ August 2007. Time series plots (Figure $3 \mathrm{~b}$ ) of soil dust markers ( $\mathrm{Al}, \mathrm{Si}, \mathrm{Ca}$, and $\mathrm{Fe}$ ) in the $\mathrm{PM}_{2.5-10}$ fraction were also examined. The smoothness of their graphs suggests similar source origin as the same dates; $9^{\text {th }}$ and $16^{\text {th }}$ August 2007 for highest and lowest concentrations. For $\mathrm{PM}_{25}, \mathrm{~K} / \mathrm{S}$ and $\mathrm{V} / \mathrm{Ni}$ concentration time series graphs were plotted in Figure $3 \mathrm{c}$ and $3 \mathrm{~d}$ respectively. Potassium and Sulphur displayed similar time trends. For instance, $S$ registered $0.4 \mu \mathrm{g} \mathrm{m}^{-3}$ (highest) and $4.0^{*} 10^{-4}$ (lowest) concentration values on $28^{\text {th }}$ July and $17^{\text {th }}$ September 2007 respectively. The same date trend also followed for $\mathrm{K}\left(0.2 \mu \mathrm{g} \mathrm{m}^{-3}\right)$ and $\left(4.5^{*} 10^{-3} \mathrm{\mu g} \mathrm{m}^{-3}\right)$ highest and lowest concentrations. Conversely, time series graph (Figure $3 \mathrm{~d}$ ) of $\mathrm{V}$ and $\mathrm{Ni}$ detected in fine fraction showed that their highest and lowest concentrations were registered in different dates.

\section{Comparison of elemental concentrations}

In Tables 4 and 5, $\mathrm{PM}_{2.5-10}$ and $\mathrm{PM}_{2.5}$ elemental concentrations were compared with values reported in previous measurements in Nigeria and elsewhere. For $\mathrm{PM}_{2.5-10}$ (Table 4), average concentration $\left(0.8 \mu \mathrm{g} \mathrm{m}^{-3}\right)$ of $\mathrm{Na}$ reported for this study were much lower than values $\left(21.2 \mu \mathrm{g} \mathrm{m}^{-3}\right.$ and $2.7 \mu \mathrm{g} \mathrm{m}^{-3}$ ) for Addis Ababa [25] and Kenitra [26] respectively. This could be due to many reasons such as geographical locations, time, height and duration of sampling. Aluminium average concentrations in the coarse particulates were in the order; $3.9 \mu \mathrm{g} \mathrm{m}^{-3}$ (Francis Town) $>2.5$ $\mu \mathrm{g} \mathrm{m}^{-3}$ (Addis Ababa) $>2.3 \mu \mathrm{g} \mathrm{m}^{-3}$ (Cairo) $>1.8 \mu \mathrm{g} \mathrm{m}^{-3}$ (Kenitra) and 0.6 $\mu \mathrm{g} \mathrm{m}^{-3}$ (this study). Chlorine average concentrations were in the order; $15.9 \mu \mathrm{g} \mathrm{m}^{-3}$ (Cairo) $>4.5 \mu \mathrm{g} \mathrm{m}^{-3}$ (Dar es Salaam) $>1.1 \mu \mathrm{g} \mathrm{m}^{-3}$ (this study, coarse fraction) $>0.5 \mu \mathrm{g} \mathrm{m}^{-3}$ (Nairobi) $>0.2 \mu \mathrm{g} \mathrm{m}^{-3}$ (Francis Town). High concentration of $\mathrm{Cl}$ in Egypt could be due to location of the sampling site; Cairo is situated in delta region of Nile River, hence high impact of sea spray emission to pollutant load in its air-shed is expected. Sulphur average concentration $\left(0.5 \mu \mathrm{g} \mathrm{m}^{-3}\right)$ in this study (coarse fraction) was higher than value for Nairobi but was comparable to value for Abuja, Nigeria. Potassium concentration was highest in Addis Ababa and lowest at Francis Town. Addis Ababa $\left(40.2 \mu \mathrm{g} \mathrm{m}^{-3}\right)$ and Francis Town 
Citation: Ezeh GC, Obioh IB, Asubiojo OI (2017) Trace Metals and Source Identification of Air-Borne Particulate Matter Pollution in A Nigerian Megacity. J Environ Anal Toxicol 7: 463. doi: 10.4172/2161-0525.1000463

Page 6 of 11

\begin{tabular}{|c|c|c|c|c|c|c|c|c|c|c|c|c|c|c|c|c|c|c|c|c|c|c|c|c|}
\hline & $\mathrm{Na}$ & $\mathrm{Mg}$ & $\mathrm{Al}$ & $\mathrm{Si}$ & $P$ & $S$ & $\mathrm{Cl}$ & $\mathrm{K}$ & $\mathrm{Ca}$ & $\mathrm{Ti}$ & V & $\mathrm{Cr}$ & $\mathrm{Mn}$ & $\mathrm{Fe}$ & $\mathrm{Ni}$ & $\mathrm{Cu}$ & $\mathrm{Zn}$ & $\mathrm{Se}$ & $\mathrm{Br}$ & $\mathrm{Rb}$ & $\mathrm{Sr}$ & $\mathrm{Zr}$ & Cs & $\mathrm{Pb}$ \\
\hline $\mathrm{Na}$ & 1.00 & & & & & & & & & & & & & & & & & & & & & & & \\
\hline $\mathrm{Mg}$ & 0.86 & 1.00 & & & & & & & & & & & & & & & & & & & & & & \\
\hline $\mathrm{Al}$ & 0.61 & 0.88 & 1.00 & & & & & & & & & & & & & & & & & & & & & \\
\hline $\mathrm{Si}$ & 0.60 & 0.88 & 0.99 & 1.00 & & & & & & & & & & & & & & & & & & & & \\
\hline$P$ & 0.54 & 0.62 & 0.57 & 0.59 & 1.00 & & & & & & & & & & & & & & & & & & & \\
\hline$S$ & 0.76 & 0.92 & 0.88 & 0.89 & 0.61 & 1.00 & & & & & & & & & & & & & & & & & & \\
\hline $\mathrm{Cl}$ & 0.95 & 0.86 & 0.65 & 0.65 & 0.51 & 0.77 & 1.00 & & & & & & & & & & & & & & & & & \\
\hline $\mathrm{K}$ & 0.76 & 0.94 & 0.93 & 0.92 & 0.60 & 0.96 & 0.78 & 1.00 & & & & & & & & & & & & & & & & \\
\hline $\mathrm{Ca}$ & 0.57 & 0.86 & 0.90 & 0.92 & 0.54 & 0.92 & 0.64 & 0.90 & 1.00 & & & & & & & & & & & & & & & \\
\hline $\mathrm{Ti}$ & 0.60 & 0.88 & 1.00 & 0.99 & 0.56 & 0.88 & 0.65 & 0.93 & 0.90 & 1.00 & & & & & & & & & & & & & & \\
\hline $\mathrm{V}$ & 0.24 & 0.38 & 0.44 & 0.51 & 0.36 & 0.51 & 0.30 & 0.39 & 0.49 & 0.45 & 1.00 & & & & & & & & & & & & & \\
\hline $\mathrm{Cr}$ & 0.40 & 0.65 & 0.72 & 0.71 & 0.42 & 0.72 & 0.43 & 0.72 & 0.78 & 0.71 & 0.29 & 1.00 & & & & & & & & & & & & \\
\hline $\mathrm{Mn}$ & 0.63 & 0.90 & 0.95 & 0.96 & 0.61 & 0.92 & 0.66 & 0.91 & 0.94 & 0.95 & 0.53 & 0.75 & 1.00 & & & & & & & & & & & \\
\hline $\mathrm{Fe}$ & 0.62 & 0.89 & 0.99 & 1.00 & 0.60 & 0.90 & 0.67 & 0.93 & 0.93 & 0.99 & 0.52 & 0.73 & 0.97 & 1.00 & & & & & & & & & & \\
\hline $\mathrm{Ni}$ & 0.35 & 0.48 & 0.45 & 0.53 & 0.44 & 0.60 & 0.42 & 0.46 & 0.57 & 0.46 & 0.85 & 0.34 & 0.58 & 0.54 & 1.00 & & & & & & & & & \\
\hline $\mathrm{Cu}$ & 0.64 & 0.87 & 0.83 & 0.85 & 0.73 & 0.89 & 0.67 & 0.86 & 0.88 & 0.83 & 0.52 & 0.70 & 0.91 & 0.88 & 0.62 & 1.00 & & & & & & & & \\
\hline $\mathrm{Zn}$ & 0.48 & 0.61 & 0.51 & 0.54 & 0.68 & 0.68 & 0.46 & 0.60 & 0.63 & 0.51 & 0.39 & 0.51 & 0.62 & 0.57 & 0.53 & 0.77 & 1.00 & & & & & & & \\
\hline $\mathrm{Se}$ & 0.60 & 0.72 & 0.70 & 0.69 & 0.37 & 0.66 & 0.60 & 0.70 & 0.65 & 0.69 & 0.29 & 0.53 & 0.68 & 0.68 & 0.32 & 0.60 & 0.24 & 1.00 & & & & & & \\
\hline $\mathrm{Br}$ & 0.83 & 0.90 & 0.79 & 0.79 & 0.55 & 0.87 & 0.87 & 0.89 & 0.77 & 0.79 & 0.30 & 0.58 & 0.79 & 0.81 & 0.44 & 0.77 & 0.54 & 0.66 & 1.00 & & & & & \\
\hline $\mathrm{Rb}$ & 0.63 & 0.86 & 0.92 & 0.93 & 0.55 & 0.90 & 0.67 & 0.92 & 0.88 & 0.93 & 0.55 & 0.68 & 0.92 & 0.94 & 0.55 & 0.84 & 0.54 & 0.63 & 0.78 & 1.00 & & & & \\
\hline $\mathrm{Sr}$ & 0.58 & 0.87 & 0.90 & 0.92 & 0.53 & 0.90 & 0.64 & 0.89 & 0.98 & 0.91 & 0.53 & 0.75 & 0.93 & 0.93 & 0.58 & 0.87 & 0.55 & 0.66 & 0.77 & 0.89 & 1.00 & & & \\
\hline $\mathrm{Zr}$ & 0.49 & 0.77 & 0.91 & 0.89 & 0.49 & 0.76 & 0.53 & 0.82 & 0.79 & 0.92 & 0.36 & 0.69 & 0.86 & 0.89 & 0.33 & 0.71 & 0.44 & 0.58 & 0.66 & 0.83 & \begin{tabular}{|l|} 
\\
\end{tabular} & 1.00 & & \\
\hline Cs & -0.21 & -0.27 & -0.32 & -0.23 & -0.03 & -0.15 & -0.15 & -0.32 & -0.15 & -0.32 & 0.46 & -0.24 & -0.16 & -0.22 & 0.51 & -0.03 & 0.00 & -0.22 & -0.20 & -0.20 & -0.12 & -0.38 & 1.00 & \\
\hline $\mathrm{Pb}$ & 0.42 & 0.63 & 0.64 & 0.66 & 0.49 & 0.73 & 0.41 & 0.68 & 0.68 & 0.63 & 0.43 & 0.67 & 0.75 & 0.69 & 0.52 & 0.77 & 0.83 & 0.34 & 0.57 & 0.66 & 0.63 & 0.59 & -0.06 & 1.00 \\
\hline
\end{tabular}

Bolded cells mean that correlation is significant at the 0.05 level (2-tailed)

Table 2: Elemental correlation analysis of $\mathrm{PM}_{2.5-10}$ aerosols.

\begin{tabular}{|c|c|c|c|c|c|c|c|c|c|c|c|c|c|c|c|c|c|c|c|c|c|c|c|c|}
\hline & $\mathrm{Na}$ & $\mathbf{M g}$ & Al & Si & $\mathbf{P}$ & $S$ & $\mathrm{Cl}$ & $\mathrm{K}$ & $\mathrm{Ca}$ & $\mathrm{Ti}$ & V & $\mathrm{Cr}$ & Mn & $\mathrm{Fe}$ & $\mathrm{Ni}$ & $\mathrm{Cu}$ & $\mathrm{Zn}$ & Se & $\mathrm{Br}$ & $\mathbf{R b}$ & $\mathrm{Sr}$ & $\mathrm{Zr}$ & Cs & $\mathrm{Pb}$ \\
\hline $\mathrm{Na}$ & 1.00 & & & & & & & & & & & & & & & & & & & & & & & \\
\hline $\mathbf{M g}$ & 0.87 & 1.00 & & & & & & & & & & & & & & & & & & & & & & \\
\hline Al & 0.41 & 0.60 & 1.00 & & & & & & & & & & & & & & & & & & & & & \\
\hline $\mathbf{S i}$ & 0.48 & 0.64 & 0.97 & 1.00 & & & & & & & & & & & & & & & & & & & & \\
\hline $\mathbf{P}$ & 0.54 & 0.58 & 0.47 & 0.56 & 1.00 & & & & & & & & & & & & & & & & & & & \\
\hline $\mathbf{s}$ & 0.84 & 0.78 & 0.50 & 0.58 & 0.53 & 1.00 & & & & & & & & & & & & & & & & & & \\
\hline $\mathrm{Cl}$ & 0.57 & 0.66 & 0.66 & 0.74 & 0.45 & 0.57 & 1.00 & & & & & & & & & & & & & & & & & \\
\hline $\mathrm{K}$ & 0.80 & 0.77 & 0.58 & 0.66 & 0.87 & 0.94 & 0.61 & 1.00 & & & & & & & & & & & & & & & & \\
\hline $\mathrm{Ca}$ & 0.19 & 0.31 & 0.74 & 0.75 & 0.32 & 0.28 & 0.47 & 0.33 & 1.00 & & & & & & & & & & & & & & & \\
\hline $\mathrm{Ti}$ & 0.30 & 0.40 & 0.95 & 0.71 & 0.39 & 0.39 & 0.46 & 0.46 & 0.59 & 1.00 & & & & & & & & & & & & & & \\
\hline $\mathbf{V}$ & 0.05 & 0.00 & -0.02 & 0.02 & -0.11 & 0.31 & -0.10 & 0.21 & 0.01 & 0.10 & 1.00 & & & & & & & & & & & & & \\
\hline $\mathrm{Cr}$ & 0.52 & 0.66 & 0.66 & 0.70 & 0.68 & 0.52 & 0.81 & 0.55 & 0.40 & 0.40 & -0.08 & 1.00 & & & & & & & & & & & & \\
\hline$M n$ & 0.13 & 0.05 & 0.26 & 0.28 & -0.03 & 0.38 & 0.03 & 0.32 & 0.24 & 0.31 & 0.49 & 0.04 & 1.00 & & & & & & & & & & & \\
\hline $\mathrm{Fe}$ & 0.40 & 0.54 & 0.92 & 0.95 & 0.45 & 0.54 & 0.65 & 0.61 & 0.83 & 0.75 & 0.13 & 0.61 & 0.39 & 1.00 & & & & & & & & & & \\
\hline $\mathrm{Ni}$ & 0.35 & 0.40 & 0.38 & 0.42 & 0.34 & 0.49 & 0.40 & 0.44 & 0.21 & 0.27 & 0.98 & 0.42 & 0.43 & 0.43 & 1.00 & & & & & & & & & \\
\hline $\mathrm{Cu}$ & 0.35 & 0.30 & 0.23 & 0.33 & 0.43 & 0.41 & 0.37 & 0.36 & 0.30 & 0.36 & 0.15 & 0.33 & 0.36 & 0.38 & 0.38 & 1.00 & & & & & & & & \\
\hline $\mathrm{Zn}$ & 0.31 & 0.24 & 0.18 & 0.25 & 0.41 & 0.30 & 0.33 & 0.25 & 0.22 & 0.21 & 0.62 & 0.32 & 0.78 & 0.25 & 0.35 & 0.83 & 1.00 & & & & & & & \\
\hline Se & 0.78 & 0.80 & 0.54 & 0.59 & 0.65 & 0.76 & 0.63 & 0.73 & 0.30 & 0.40 & 0.06 & 0.67 & 0.14 & 0.51 & 0.43 & 0.29 & 0.24 & 1.00 & & & & & & \\
\hline $\mathrm{Br}$ & 0.66 & 0.74 & 0.72 & 0.57 & 0.67 & 0.80 & 0.78 & 0.83 & 0.38 & 0.46 & 0.06 & 0.75 & 0.18 & 0.68 & 0.45 & 0.30 & 0.21 & 0.72 & 1.00 & & & & & \\
\hline Rb & 0.58 & 0.49 & 0.39 & 0.46 & 0.47 & 0.55 & 0.47 & 0.64 & 0.26 & 0.37 & 0.01 & 0.41 & 0.30 & 0.43 & 0.25 & 0.37 & 0.41 & 0.47 & 0.44 & 1.00 & & & & \\
\hline $\mathrm{Sr}$ & 0.25 & 0.36 & 0.53 & 0.55 & 0.38 & 0.40 & 0.54 & 0.44 & 0.54 & 0.39 & 0.07 & 0.41 & 0.06 & 0.55 & 0.31 & 0.30 & 0.18 & 0.33 & 0.56 & 0.21 & 1.00 & & & \\
\hline $\mathrm{Zr}$ & 0.42 & 0.54 & 0.89 & 0.84 & 0.56 & 0.55 & 0.66 & 0.56 & 0.38 & 0.41 & 0.07 & 0.63 & 0.11 & 0.58 & 0.36 & 0.25 & 0.18 & 0.50 & 0.72 & 0.27 & 0.44 & 1.00 & & \\
\hline Cs & -0.13 & -0.21 & -0.22 & -0.22 & -0.33 & -0.02 & -0.41 & -0.13 & -0.17 & 0.02 & 0.37 & -0.35 & 0.36 & -0.16 & 0.10 & 0.00 & -0.02 & -0.15 & -0.25 & -0.17 & -0.19 & -0.22 & 1.00 & \\
\hline $\mathrm{Pb}$ & 0.33 & 0.32 & 0.22 & 0.29 & 0.10 & 0.70 & 0.17 & 0.43 & 0.18 & 0.21 & 0.29 & 0.12 & 0.44 & 0.31 & 0.30 & 0.23 & 0.13 & 0.21 & 0.78 & 0.28 & 0.16 & 0.31 & 0.16 & 1.00 \\
\hline
\end{tabular}

Bolded cells mean that correlation is significant at the 0.05 level (2-tailed).

Table 3: Elemental correlation analysis of $\mathrm{PM}_{2.5}$ aerosols.

$\left(0.7 \mu \mathrm{g} \mathrm{m}^{-3}\right)$ represents highest and lowest average concentration of Ca. Iron was highest $\left(3.1 \mu \mathrm{g} \mathrm{m}^{-3}\right)$ in Cairo and lowest $\left(0.6 \mu \mathrm{g} \mathrm{m}^{-3}\right)$ in Dar és Salaam. We observed that $\mathrm{Pb}$ concentrations $\left(7 \mathrm{ng} \mathrm{m}^{-3}\right)$ in this study was lower than 0.2 and $6.9 \mu \mathrm{g} \mathrm{m}^{-3}$ reported for Kenitra and Cairo respectively but was comparable to the values of $6,11,12,18$ and 29 $\mathrm{ng} \mathrm{m}^{-3}$ reported for Francis Town, Abuja, Dar es Salaam, Ikoyi and Nairobi respectively. 
Citation: Ezeh GC, Obioh IB, Asubiojo OI (2017) Trace Metals and Source Identification of Air-Borne Particulate Matter Pollution in A Nigerian Megacity. J Environ Anal Toxicol 7: 463. doi: 10.4172/2161-0525.1000463

Page 7 of 11

\begin{tabular}{|c|c|c|c|c|c|c|c|c|}
\hline \multirow{3}{*}{$\begin{array}{l}\frac{m}{\mathbb{D}} \\
\frac{\mathrm{D}}{3} \\
\frac{\Phi}{\vec{D}}\end{array}$} & \multirow[b]{2}{*}{ This study } & Abiye et a.l (2013) & Gebre et al. (2010) & Gatari et al. (2008) & Tahri et al. 2013 & Gebre et al. (2010) & Gatari et al. (2008) & Tahri et al. 2013 \\
\hline & & Abuja, Nigeria & $\begin{array}{l}\text { Addis Ababa, } \\
\text { Ethiopia }\end{array}$ & $\begin{array}{l}\text { Nairobi } \\
\text { Kenya }\end{array}$ & $\begin{array}{l}\text { Cairo } \\
\text { Egypt }\end{array}$ & $\begin{array}{l}\text { Francis Town, } \\
\text { Botswana }\end{array}$ & $\begin{array}{c}\text { Dar es Salaam, } \\
\text { Tanzania }\end{array}$ & $\begin{array}{l}\text { Kenitra } \\
\text { Morocco }\end{array}$ \\
\hline & $2.5<\mathrm{d}_{\mathrm{ae}}<10 \mu \mathrm{m}$ & $2.5<d_{a e}<10 \mu m$ & $d_{a e}<10 \mu m$ & $2.5<\mathrm{d}_{\mathrm{ae}}<10 \mu \mathrm{m}$ & $d_{a e}<10 \mu m$ & $2<\mathrm{d}_{\mathrm{ae}}<10 \mu \mathrm{m}$ & $2<d_{a e}<10 \mu m$ & $2.5<d_{a e}<10 \mu m$ \\
\hline $\mathrm{Na}$ & 819 & - & 21217 & - & - & - & - & 2707 \\
\hline $\mathrm{Mg}$ & 235 & - & 1400 & - & - & - & - & - \\
\hline $\mathrm{Al}$ & 616 & - & 2495 & - & 2333 & 3900 & - & 1848 \\
\hline $\mathrm{Si}$ & 1525 & 11734 & - & 2300 & 7867 & $<\mathrm{DL}$ & 680 & - \\
\hline $\mathrm{P}$ & 20 & - & - & - & - & - & - & - \\
\hline$S$ & 485 & 833 & - & 250 & - & - & - & - \\
\hline $\mathrm{Cl}$ & 1095 & - & - & 450 & 15867 & 230 & 4500 & - \\
\hline $\mathrm{K}$ & 281 & 2249 & 7687 & 650 & - & 350 & 420 & 1432 \\
\hline $\mathrm{Ca}$ & 1789 & 3528 & 40167 & 1000 & 13083 & 690 & 4900 & 11300 \\
\hline $\mathrm{Ti}$ & 78 & 246 & 67 & 190 & - & 110 & 100 & - \\
\hline V & 4 & 13 & 18 & - & - & - & - & - \\
\hline $\mathrm{Cr}$ & 3 & 89 & 681 & - & - & - & - & 61 \\
\hline $\mathrm{Mn}$ & 12 & 45 & 106 & 180 & - & 28 & 27 & 70 \\
\hline $\mathrm{Fe}$ & 640 & 1984 & 1250 & 2300 & 3083 & 1300 & 610 & 2051 \\
\hline $\mathrm{Ni}$ & 2 & 24 & 10 & 1.8 & - & - & - & 137 \\
\hline $\mathrm{Cu}$ & 5 & 667 & 113 & 7.3 & - & - & - & 144 \\
\hline $\mathrm{Zn}$ & 42 & 41 & 2612 & 57 & - & 6.9 & 40 & 634 \\
\hline $\mathrm{Se}$ & 1 & - & - & - & - & - & - & - \\
\hline $\mathrm{Br}$ & 7 & - & - & 15 & - & 1.9 & 3.1 & - \\
\hline $\mathrm{Rb}$ & 3 & - & 33 & 3 & - & - & - & - \\
\hline $\mathrm{Sr}$ & 7 & - & - & - & - & - & - & - \\
\hline $\mathrm{Zr}$ & 3 & - & - & - & - & - & - & - \\
\hline Cs & 1 & - & - & - & - & - & - & - \\
\hline $\mathrm{Pb}$ & 7 & 11 & - & 29 & 6850 & 5.6 & 12 & 196 \\
\hline
\end{tabular}

Table 4: Comparison of $\mathrm{PM}_{2.5-10}$ elemental concentrations $\left(\mathrm{ng} \mathrm{m}^{-3}\right)$.

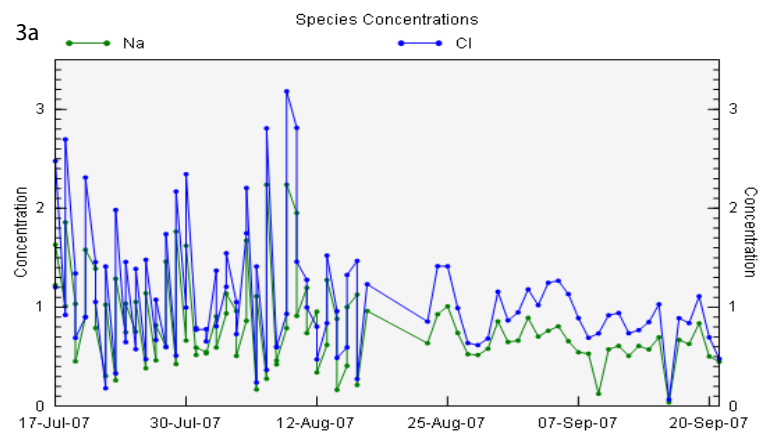

$3 \mathrm{~b}: \begin{array}{cr}\mathrm{Al} \\ \mathrm{Ca} & \text { Species Concentrations } \\ \mathrm{C} & \mathrm{Si} \\ \mathrm{Fe}\end{array}$

3c $\because$ s $\quad$ Species concentrations
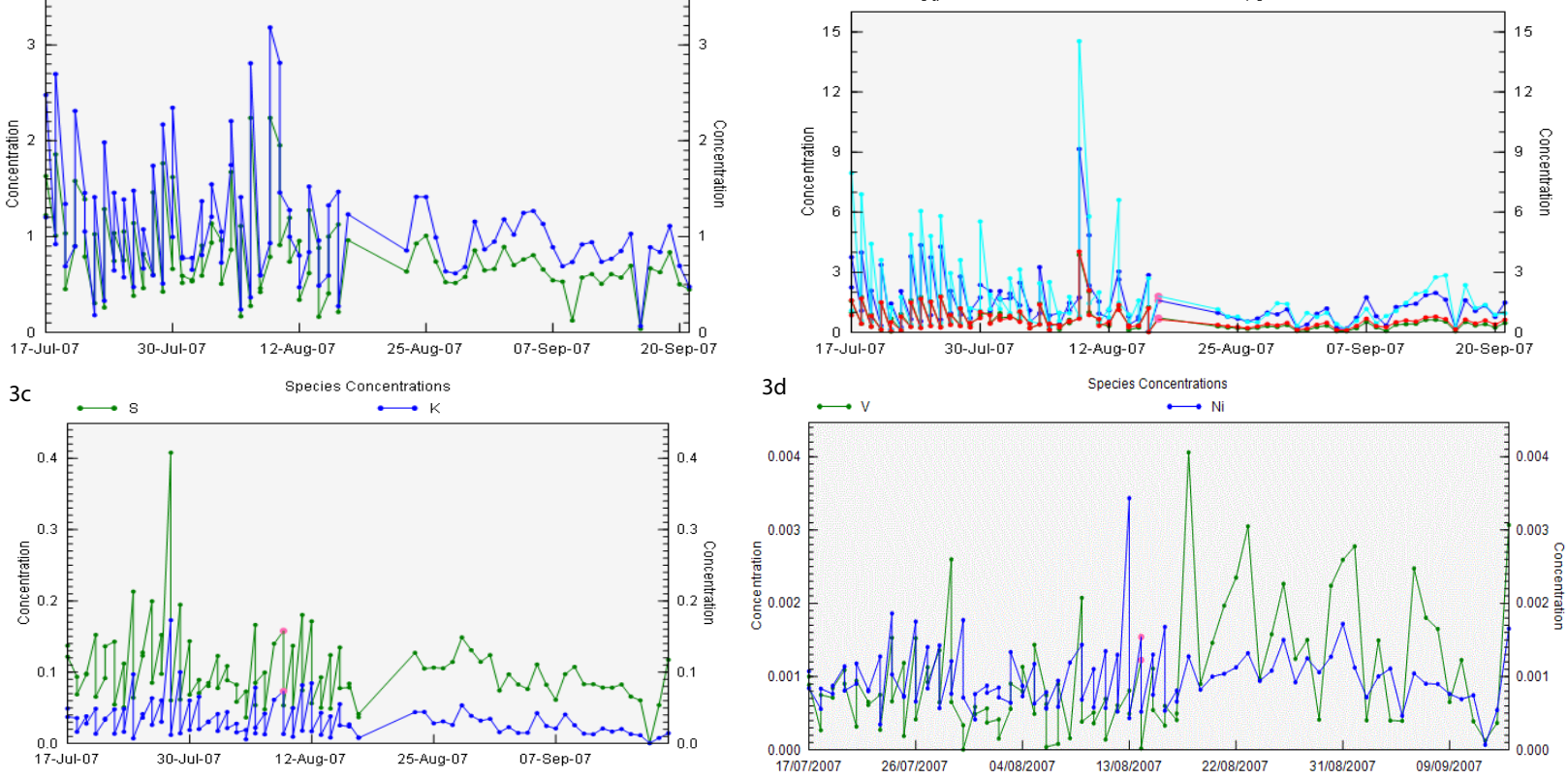

Figure 3: a) Coarse particulate $\mathrm{Na}$ and $\mathrm{Cl}$ time series plots $\left(\mu \mathrm{g} \mathrm{m}^{-3}\right)$, b): Coarse particulate a Al, Ca, Si and Fe time series plots $\left(\mu \mathrm{g} \mathrm{m}^{-3}\right)$, c) Fine particulate $S$ and $\mathrm{K}$ time series plots $\left(\mu \mathrm{g} \mathrm{m}^{-3}\right)$, d) Fine particulate $\mathrm{V}$ and Ni time series plots $\left(\mu \mathrm{g} \mathrm{m}^{-3}\right)$.

For $\mathrm{PM}_{2.5}$ fraction (Table 5), average elemental concentrations reported in this study were in most cases lower than values for other

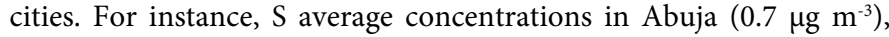

Nairobi $\left(1.3 \mu \mathrm{g} \mathrm{m}^{-3}\right)$, Francistown $\left(0.3 \mu \mathrm{g} \mathrm{m}^{-3}\right)$, and Tanzania (1.0 $\mathrm{ng}$

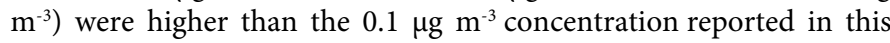
study. 
Citation: Ezeh GC, Obioh IB, Asubiojo OI (2017) Trace Metals and Source Identification of Air-Borne Particulate Matter Pollution in A Nigerian Megacity. J Environ Anal Toxicol 7: 463. doi: 10.4172/2161-0525.1000463

Page 8 of 11

\begin{tabular}{|c|c|c|c|c|c|c|c|c|}
\hline \multirow{3}{*}{$\begin{array}{l}\frac{m}{\mathbb{D}} \\
\vec{\nabla} \\
\stackrel{\mathbb{D}}{\vec{p}} \\
\vec{\omega}\end{array}$} & \multirow[b]{2}{*}{ This study } & Abiye et a.l (2013) & Gebre et al. (2010) & Gatari et al. (2008) & Tahri et al. 2013 & Gebre et al. (2010) & Gatari et al. (2008) & Tahri et al. 2013 \\
\hline & & Abuja, Nigeria & $\begin{array}{l}\text { Addis Ababa, } \\
\text { Ethiopia }\end{array}$ & $\begin{array}{l}\text { Nairobi } \\
\text { Kenya }\end{array}$ & $\begin{array}{l}\text { Cairo } \\
\text { Egypt }\end{array}$ & $\begin{array}{l}\text { Francis Town, } \\
\text { Botswana }\end{array}$ & $\begin{array}{l}\text { Dar es Salaam, } \\
\text { Tanzania }\end{array}$ & $\begin{array}{c}\text { Kenitra } \\
\text { Morocco }\end{array}$ \\
\hline & $2.5<\mathrm{d}_{\mathrm{ae}}<10 \mu \mathrm{m}$ & $2.5<\mathrm{d}_{\mathrm{ae}}<10 \mu \mathrm{m}$ & $d_{a e}<10 \mu m$ & $2.5<\mathrm{d}_{\mathrm{ae}}<10 \mu \mathrm{m}$ & $d_{a e}<10 \mu m$ & $2<\mathrm{d}_{\mathrm{ae}}<10 \mu \mathrm{m}$ & $2<\mathrm{dae}_{a}<10 \mu \mathrm{m}$ & $2.5<\mathrm{d}_{\mathrm{ae}}<10 \mu \mathrm{m}$ \\
\hline $\mathrm{Na}$ & 819 & - & 21217 & - & - & - & - & 2707 \\
\hline $\mathrm{Mg}$ & 235 & - & 1400 & - & - & - & - & - \\
\hline $\mathrm{Al}$ & 616 & - & 2495 & - & 2333 & 3900 & - & 1848 \\
\hline $\mathrm{Si}$ & 1525 & 11734 & - & 2300 & 7867 & $<\mathrm{DL}$ & 680 & - \\
\hline $\mathrm{P}$ & 20 & - & - & - & - & - & - & - \\
\hline$S$ & 485 & 833 & - & 250 & - & - & - & - \\
\hline $\mathrm{Cl}$ & 1095 & - & - & 450 & 15867 & 230 & 4500 & - \\
\hline $\mathrm{K}$ & 281 & 2249 & 7687 & 650 & - & 350 & 420 & 1432 \\
\hline $\mathrm{Ca}$ & 1789 & 3528 & 40167 & 1000 & 13083 & 690 & 4900 & 11300 \\
\hline $\mathrm{Ti}$ & 78 & 246 & 67 & 190 & - & 110 & 100 & - \\
\hline V & 4 & 13 & 18 & - & - & - & - & - \\
\hline $\mathrm{Cr}$ & 3 & 89 & 681 & - & - & - & - & 61 \\
\hline $\mathrm{Mn}$ & 12 & 45 & 106 & 180 & - & 28 & 27 & 70 \\
\hline $\mathrm{Fe}$ & 640 & 1984 & 1250 & 2300 & 3083 & 1300 & 610 & 2051 \\
\hline $\mathrm{Ni}$ & 2 & 24 & 10 & 1.8 & - & - & - & 137 \\
\hline $\mathrm{Cu}$ & 5 & 667 & 113 & 7.3 & - & - & - & 144 \\
\hline $\mathrm{Zn}$ & 42 & 41 & 2612 & 57 & - & 6.9 & 40 & 634 \\
\hline Se & 1 & - & - & - & - & - & - & - \\
\hline $\mathrm{Br}$ & 7 & - & - & 15 & - & 1.9 & 3.1 & - \\
\hline $\mathrm{Rb}$ & 3 & - & 33 & 3 & - & - & - & - \\
\hline $\mathrm{Sr}$ & 7 & - & - & - & - & - & - & - \\
\hline $\mathrm{Zr}$ & 3 & - & - & - & - & - & - & - \\
\hline Cs & 1 & - & - & - & - & - & - & - \\
\hline $\mathrm{Pb}$ & 7 & 11 & - & 29 & 6850 & 5.6 & 12 & 196 \\
\hline
\end{tabular}

" $\mathrm{dae}$ " means "aerodynamic diameter"; "< DL" means "less than detection limit"; "- "denotes "not detected

Table 4: Comparison of $\mathrm{PM}_{2.5-10}$ elemental concentrations $\left(\mathrm{ng} \mathrm{m}^{-3}\right)$.

\begin{tabular}{|c|c|c|c|c|c|c|c|}
\hline$S$ & 100 & 700 & 1300 & 320 & 1000 & - & - \\
\hline $\mathrm{Cl}$ & 36 & - & & 77 & 1200 & 10200 & - \\
\hline $\mathrm{K}$ & 33 & 878 & 730 & 320 & 350 & - & 397 \\
\hline $\mathrm{Ca}$ & 48 & 952 & 70 & 55 & 270 & 300 & - \\
\hline $\mathrm{Ti}$ & 78 & 69 & 9 & 8 & 8 & - & - \\
\hline $\mathrm{V}$ & 4 & 11 & 3 & - & - & - & - \\
\hline $\mathrm{Cr}$ & 3 & 135 & - & - & - & - & 81 \\
\hline $\mathrm{Mn}$ & 12 & 24 & 12 & 3 & 3 & - & 21 \\
\hline $\mathrm{Fe}$ & 640 & 871 & 130 & 110 & 44 & 933 & 1939 \\
\hline $\mathrm{Ni}$ & 2 & 9 & 3 & - & - & - & 161 \\
\hline $\mathrm{Cu}$ & 5 & 613 & 4 & - & - & - & 240 \\
\hline $\mathrm{Zn}$ & 42 & 22 & 100 & 5 & 9 & - & 1301 \\
\hline $\mathrm{Se}$ & - & - & - & - & - & - & - \\
\hline $\mathrm{Br}$ & 1 & - & 36 & 9 & 9 & - & - \\
\hline $\mathrm{Rb}$ & - & - & 2 & - & - & - & - \\
\hline Cs & 2 & - & - & - & - & - & - \\
\hline $\mathrm{Pb}$ & 1 & 15 & 76 & 11 & 25 & 2000 & 303 \\
\hline
\end{tabular}

Table 5: Comparison of $\mathrm{PM}_{2.5}$ elemental concentrations $\left(\mathrm{ng} \mathrm{m}^{-3}\right)$.

Similarly, $\mathrm{K}$ concentration $\left(33 \mathrm{ng} \mathrm{m}^{-3}\right.$ ) was also lower than values reported for other cities. Several factors such as sampling height, time and period as well as types of samplers could contribute to these differences. For instance, in Francistown Botswana, $\mathrm{PM}_{2.5}$ was sampled at $1.5 \mathrm{~m}$ above ground level while in Nairobi; $\mathrm{PM}_{2.5}$ was sampled at an elevation of $25 \mathrm{~m}$. However, average concentration of Ca in this fraction was close to 70 and $55 \mathrm{ng} \mathrm{m}^{-3}$ values for Nairobi and Francistown respectively but differs considerably with $1.0 \mu \mathrm{g} \mathrm{m}{ }^{3}$ for Abuja. Average concentrations for heavy oil combustion related elements ( $\mathrm{V}$ and $\mathrm{Ni}$ ) were close to values for other cities (Table 5). On the other hand, average concentration recorded for $\mathrm{Zn}\left(42 \mathrm{ng} \mathrm{m}^{-3}\right)$ in this study was comparable to values for other cities. Average concentration (1 ng $\mathrm{m}^{-3}$ ) of $\mathrm{Pb}$ in this fraction was the lowest among the cities compared. This low concentration of $\mathrm{Pb}$ in Lagos air shed is probably due to low industrialization and ban in use of leaded gasoline.

\section{Positive matrix factorization (PMF)}

PMF model was run in default robust mode to decrease the influence of extreme values on its solution. To ensure that appropriate number of factors was chosen, scaled residuals and ratio of PMFmodeled residual to input uncertainty were examined for each fraction. For final examination, PMF was applied to each data using 4 to 7 factors 
Citation: Ezeh GC, Obioh IB, Asubiojo OI (2017) Trace Metals and Source Identification of Air-Borne Particulate Matter Pollution in A Nigerian Megacity. J Environ Anal Toxicol 7: 463. doi: 10.4172/2161-0525.1000463

Page 9 of 11

and robustness of the outputs with further examination of rotational parameter, FPEAK [34]. The result showed that a five-factor solutions gave the best options for coarse and fine fractions respectively. The resolved source profiles and contributions are discussed herein.

For fine $\left(\mathrm{PM}_{2.5}\right)$ fraction (Figure 4), first factor displayed high loadings of $\mathrm{K}(84 \%)$ and $\mathrm{Br}(43 \%)$ as well as $\mathrm{S}(33 \%)$ and was identified as emissions emanating from biomass burning activities [33]. The insignificant $(\sim 0 \%)$ contribution of the factor to overall $\mathrm{PM}_{2.5}$ mass loads are quite strange as open burning of waste dumps is prevalent in Lagos. Furthermore, biomass is a major source of energy by most inhabitants of Lagos. Unfortunately, literature on source apportionment of size segregated particulates are limited in Nigeria for comparison purposes, therefore further investigations are imminent. The next factor registered high loadings of $\mathrm{Cl}(64 \%), \mathrm{Cr}$ (63\%), $\mathrm{P}(67 \%)$, $\mathrm{Sr}(46 \%), \mathrm{Mg}(44 \%)$ and $\mathrm{Na}(40 \%)$. We termed it "mixed" source because it was difficult to pin down a specific source for the profile. For instance, $\mathrm{Na}, \mathrm{Cl}$ and $\mathrm{Mg}$ are markers for sea spray emissions while $\mathrm{Ni}$ and $\mathrm{Cr}$ are markers for petroleum products combustions and smelting emissions respectively. The factor accounted for $24 \%$ of total $\mathrm{PM}_{25}$ mass loads. Factor 3 three with high loadings of $\mathrm{Zn}(70 \%)$ and $\mathrm{Cu}(35 \%)$ could be emissions emanating from industrial activities [35]. The fact that PMF apportioned $0.4 \%$ of total PMF mass load to the factor is disturbing as we expected higher contribution of industrial emissions in Lagos which hosts for over $40 \%$ of industries in Nigeria. However, the result requires further investigation. The influence of soil dust on $\mathrm{PM}_{2.5}$ aerosols was observed in the fourth factor as it displayed high loadings of $\mathrm{Al}(41 \%), \mathrm{Si}(34 \%), \mathrm{Ca}(65 \%)$, and $\mathrm{Fe}(48 \%)$. About $28 \%$ of total $\mathrm{PM}_{2.5}$ mass fraction was apportioned to this factor. High percentage of total $\mathrm{PM}_{2.5}$ contribution attributed to the factor could be due to entrained and re-suspended dust from poorly maintained road networks and unpaved workways in Lagos. The fifth factor with high loadings of $\mathrm{V}$ (80\%), $\mathrm{Ni}(48 \%), \mathrm{S}(36 \%), \mathrm{Mn}(60 \%)$ and $\mathrm{Pb}(39 \%)$ was identified as emissions from gasoline oil combustion emissions [36].
The significant loadings of $\mathrm{Mn}$ and $\mathrm{Pb}$ could be an artifact from industrial and local sources as Nigerian banned use of leaded gasoline since 2004. PMF apportioned $48 \%$ of the overall $\mathrm{PM}_{25}$ mass load to the factor. This conjecture is further supported by the fact that Lagos accounts for over $30 \%$ of petroleum products consumed in Nigeria [2].

For coarse fraction (Figure 5), the first factor with high loadings of $\mathrm{Al}(54 \%), \mathrm{Si}(47 \%), \mathrm{Fe}(40 \%), \mathrm{Ti}(60 \%)$, and $\mathrm{Zr}(68 \%)$, is a typical soil dust profile [37]. Interestingly, the overall percentage contribution (22\%) of $\mathrm{PM}_{2.5-10}$ mass apportioned to the factor is less than apportioned $28 \%$ recorded in the $\mathrm{PM}_{2.5}$ fraction. This phenomenon calls for further investigation (with different variant of receptor models) as we expected higher soil dust contribution in the $\mathrm{PM}_{2.5-10}$ fraction. Moreover, particle size analysis of soil dust revealed larger aerodynamic diameter in the range of 2.5 to $10 \mu \mathrm{m}$ aerodynamic diameter. The next PMF resolved factor was similar to first factor but showed high profile of Ca. Hence, we attributed it to emissions related to physical construction activities probably from road construction and cement factories located about $150 \mathrm{~km}$ away from sampling sites. It showed high loadings of $\mathrm{Ca}(75 \%)$ and $\mathrm{Sr}(69 \%)$ with significant loadings of soil dust markers (Al, $\mathrm{Si}, \mathrm{Fe}$ and $\mathrm{Ti}$ ). The third factor could be from emissions emanating from industrial activities. It has high loadings of $\mathrm{Zn}(57 \%)$ and $\mathrm{Pb}(46 \%)$ and it contributed about $10 \%$ to $\mathrm{PM}_{2.5-10}$ total mass loads.

However, $\mathrm{Zn}$ could also indicate vehicular emissions as it is considered as an indicator element for emissions from two-stroke vehicles due to its usage as an additive in lubricating oils. The fourth factor was identified to be contributions from biomass burning emissions [33]. Its profile is characterized with S (31\%), K (28\%) and Se $(26 \%)$ and contributed about $21 \%$ of total PM mass loads. The high percentage estimate apportioned to the factor contradicted the near zero percent registered in the $\mathrm{PM}_{25}$ fraction. Owing to the particle size of biomass source emissions (aerodynamic diameter $\leq 2.5 \mu \mathrm{m}$ ), we expected higher contribution estimate in $\mathrm{PM}_{25}$. Again, the scenario calls for further studies. The fifth factor is a typical profile of emissions

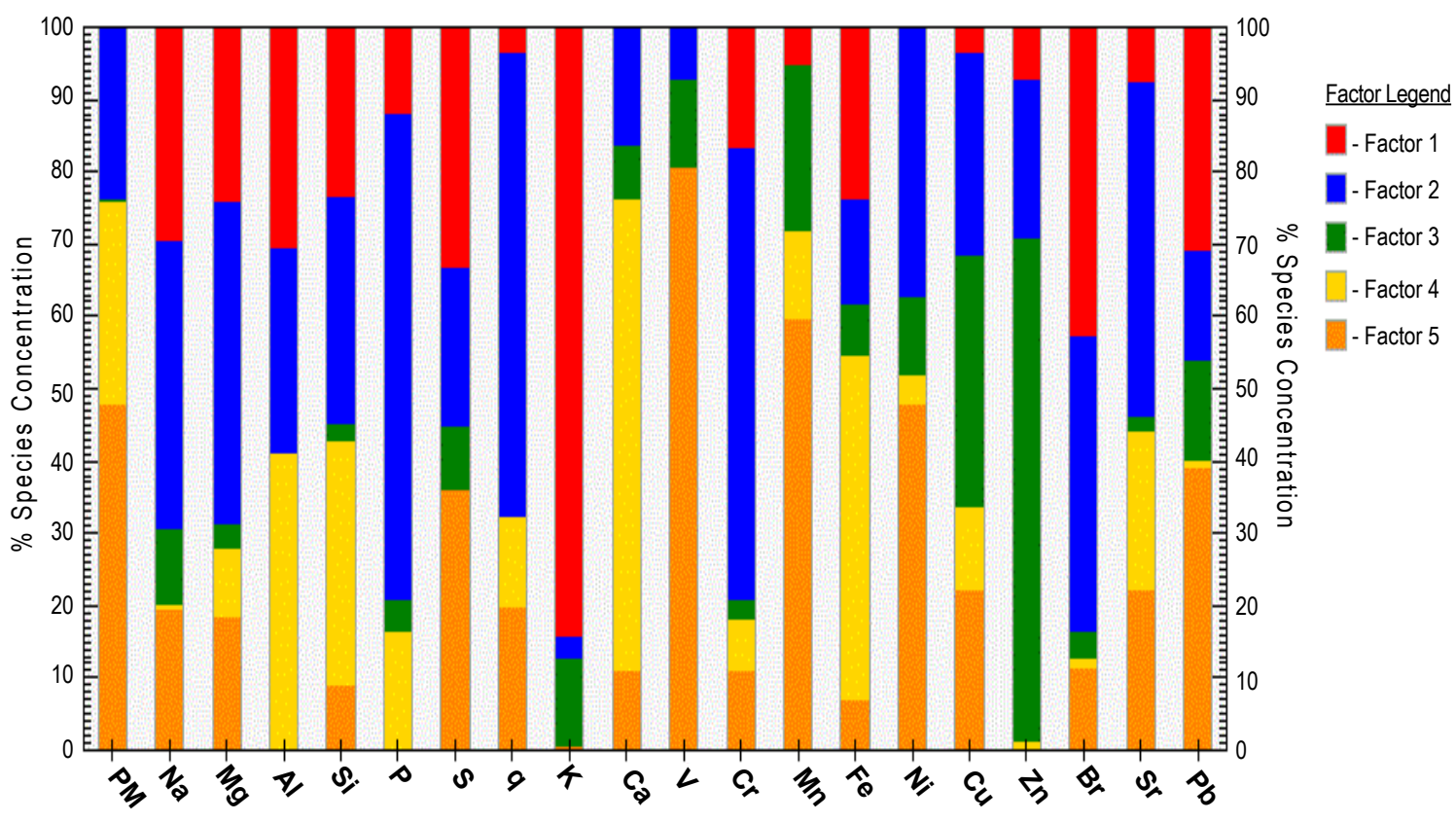

Figure 4: PMF results of $\mathrm{PM}_{2.5}$ fraction. 


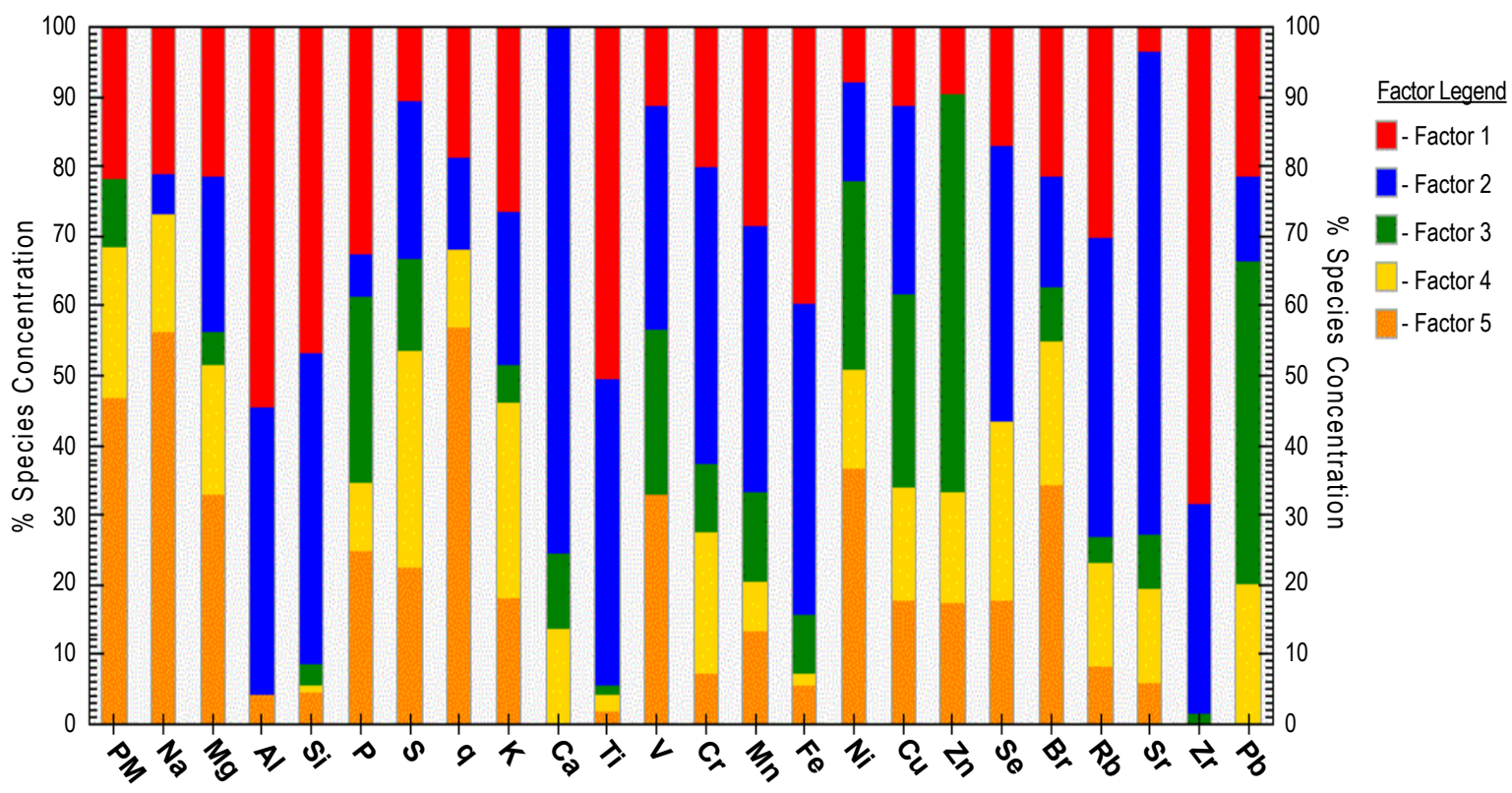

Figure 5: $\mathrm{PMF}$ results of $\mathrm{PM}_{2.5-10}$ fraction.

from marine/sea spray [37]. It displayed high loadings of $\mathrm{Na}(56 \%)$, $\mathrm{Cl}$ (57\%), $\mathrm{Mg}$ (33\%) and $\mathrm{Br}$ (34\%) which markers for sea spray. Interestingly, $47 \%$ of the $\mathrm{PM}_{2.5-10}$ overall mass was contributed by the factor probably due to location of sampling points which were situated few kilometers to the shores of Atlantic Ocean.

\section{Conclusions}

This study on source apportionment and identification of size segregated atmospheric particulates has produced a new set of more robust data of $\mathrm{PM}_{2.5}$ and $\mathrm{PM}_{10}$ concentrations in Lagos air-shed. The lowest and highest mean mass concentration of $\mathrm{PM}_{25}$ stood at $4 \mu \mathrm{g} \mathrm{m}^{-3}$ and $16 \mu \mathrm{g} \mathrm{m}^{-3}$ respectively while $\mathrm{PM}_{10}$ recorded $32 \mu \mathrm{g} \mathrm{m}^{-3}$ (lowest) to $75 \mu \mathrm{g} \mathrm{m}^{-3}$ (highest). An improved speciated set of data for elemental concentration ( $\mathrm{Na}, \mathrm{Mg}, \mathrm{Al}, \mathrm{Si}, \mathrm{P}, \mathrm{S}, \mathrm{Cl}, \mathrm{K}, \mathrm{Ca}, \mathrm{Ti}, \mathrm{V}, \mathrm{Cr}, \mathrm{Mn}, \mathrm{Fe}, \mathrm{Ni}$, $\mathrm{Cu}, \mathrm{Zn}, \mathrm{Se}, \mathrm{Br}, \mathrm{Rb}, \mathrm{Sr}, \mathrm{Zr}$, Cs and $\mathrm{Pb}$ ) of $\mathrm{PM}_{2.5}$ and $\mathrm{PM}_{2.5-10}$ have also been established using the PIXE analytical technique in an external ion beam set-up. The concentration of $\mathrm{S}$ was most pronounced in fine fraction while crustal elements $(\mathrm{Al}, \mathrm{Si}, \mathrm{Ca}$ and $\mathrm{Fe}$ ) concentrations were more prominent in the coarse fraction. Although, there are no standard guideline thresholds for most elements, continuous exposure to some of these elements could be toxic even at low concentration values. Enrichment factor calculation of elements revealed that $S$, $\mathrm{Cl}, \mathrm{Br}$ and $\mathrm{Pb}$ were highly enriched $(\mathrm{EF}>100)$ in both fractions while PIs results grouped $\mathrm{S}, \mathrm{Cl}$ and $\mathrm{Br}$ in highly pollution class for coarse fraction. The element in both fractions displayed both positive and negative correlations while time series plots revealed similar patterns for two or more markers of specific source origin. PMF resolved five for both $\mathrm{PM}_{2.5}$ and $\mathrm{PM}_{2.5-10}$ fractions of which the percentage contributions estimate for gasoline oil combustion $\left(\mathrm{PM}_{25}\right)$ and sea spray emissions contributed to over $40 \%$. High percentage estimates resolved for anthropogenic petroleum oil combustion and sea-spray calls for stringent abatement options. This work presents first known major application of PMF for source apportionment and identifications of atmospheric aerosols at receptor locations in Nigeria.

\section{Acknowledgements}

The authors are grateful to International Atomic Energy Agency (I.A.E.A.) Vienna Austria, for the NIR 12022 Postgraduate Fellowship granted to Ezeh G.C. We also acknowledge the contributions of Profs' Chiari, Nava, Calzolai and Lucarelli; all of Department of Physics and Astronomy, University of Florence and I.N.F.N., Via Sansone 1, 50019 Sesto Fiorentino (FI), Italy for facilitating the NIR 12022 programme at Florence.

\section{Conflict of Interest}

No conflict of interest was declared by the authors

\section{References}

1. National Population Commission (2007) Legal notice on publication of 2006 census final results. Federal Republic of Nigeria Official Gazette.

2. National Bureau of Statistics Annual Bulletin (2010) The Review of the Nigerian Economy. Federal Republic of Nigeria Official Gazette.

3. Obioh IB, Ezeh GC, Abiye OE, Alfa A, Ojo E, et al. (2013) Atmospheric particulate matter in Nigerian megacities. Toxicol Environ Chem 95: 379-385.

4. Oluyemi EA, Asubiojo OI, Oluwole AF, Toussaint CJN (1994) Elementa concentration and source identification of air particulate matter at a Nigerian site: a preliminary study. Radio-anal Nucl Chem 179: 187-194.

5. Olise FS, Owoade OK, Olaniyi HB (2007) An application of receptor modelling to identify airborne particulate sources in Lagos Nigeria. Ife J Sci 9: 129-136.

6. Hopke PK (2003) Recent developments in receptor modelling. Chemosphere 17: $255-265$

7. Lee PK, Brook JR, Dabek-Zlotorzynska E, Mabury SA (2003) Identification of the major sources contributing to PM2.5 observed in Toronto. Environ Sci Technol 37: 4831-4840.

8. Kim E, Hopke PK, Edgerton ES (2003) Source identification of atlanta aeroso by positive matrix factorization. J Air Waste Manag Asso 53: 731-739.

9. Zhao W, Hopke PK (2006) Source identification of fine aerosols in Mammoth Cave National Park. Atmos Res 80: 309-322.

10. Song Y, Zhang Y, Xie S, Zeng L, Zheng M, et al. (2006) Source apportionment of PM2.5 in Beijing by positive matrix factorization. Atmos Environ 40: 15261537. 
Citation: Ezeh GC, Obioh IB, Asubiojo OI (2017) Trace Metals and Source Identification of Air-Borne Particulate Matter Pollution in A Nigerian Megacity. J Environ Anal Toxicol 7: 463. doi: 10.4172/2161-0525.1000463

Page 11 of 11

11. Begum AB, Hopke PK, Markwitz A (2013) Air pollution by fine particulate matter in Bangladesh. Atmos Pollut Res 4: 75-86.

12. Murillo JH, Roman SR, Marin JFR, Ramos AC, Jimenez SB, et al. (2013) Chemical characterization and source apportionment of PM10 and PM2.5 in the metropolitan area of Costa Rica Central America. Atmos Pollut Res 4: 181-190.

13. Owoade KO, Hopke PK, Olise FS, Ogundele LT, Fawole OG, et al. (2015) Chemical compositions and source identification of particulate matter (PM2.5 and PM2.5-10) from a scrap iron and steel smelting industry along the IfeIbadan highway, Nigeria. Atmos Pollut Res 6: 107-119.

14. Maenhaut W, Salma I, Cafmeyer J, Annegarn HJ, Andreae MO (1996) Regional atmospheric aerosol composition and sources in the eastern Transvaal, South Africa, and impact of biomass burning. J Geophy Res Atmos 101: 23631-23650.

15. Ezeh GC, Obioh IB, Asubiojo OI, Abiye OE (2012) PIXE characterization of PM10 and PM2.5 particulates sizes collected in Ikoyi Lagos, Nigeria. Toxicol Environ Chem 94: 884-894

16. Calzolai G, Chiar M, Garci'a OI, Lucarelli F, Migliori A, et al. (2006) The new external beam facility for environmental studies at the Tandetron accelerator of LABEC, Italy. Nuc Inst Method Phy Res 249: 928-931.

17. Campbell JL, Boyd NI, Grassi N, Bonnick P, Maxwell JA (2010) The Guelph PIXE software package IV. Nuc Inst Method Phy Res 268: 3356-3363.

18. Mason B (1966) Principles of geochemistry. ( $3^{\text {rd }}$ Edn). Wiley: New York.

19. dos-Anjos MJ, Lopes RT, De Jesus EFO, Assis JT, Cesareo R, et al. (2000) Quantitative analysis of metals in soil using X-ray fluorescence. Spectrochim Acta (B) 55: 1189-1194.

20. Sze'kely GJ, Rizzo ML, Bakirov NK (2007) Measuring and testing dependence by correlation of distances. Ann Statistics 35: 2769-2794.

21. Norris G, Vedantham R, Wade K, Brown S, Prouty J, et al. (2008) EPA Positive matrix factorization (PMF) 3.0 fundamentals and user guide, United States Environmental Protection Agency.

22. Paatero $P$ (1997) Least square formulation of robust non-negative factor analysis. Chem Intell Laboratory Sys 37: 23-35.

23. Polissar AV, Hopke PK, Paatero P (1988) Atmospheric aerosol over Alaska elemental composition and sources. J Geophy Res Atmos 103: 19045-19057.

24. World Health Organization (2006) Air quality guidelines for particulate matter, ozone, nitrogen dioxide and sulfur dioxide global update. World Health Organization (WHO) Geneva Switzerland.
25. Gebre G, Feleke Z, Sahle-Demissie E (2010) Mass concentrations and elemental composition of urban atmospheric aerosols in Addis Ababa, Ethiopia. Bull Chem Soc Ethiopia 24: 3723-3737.

26. Tahri M, Bounakha M, Zghaid M, Noack Y, Benyaich F, et al. (2013) Evaluation of airborne particulate matter pollution in Kenitra city, Morocco. Rev Ambi Aqua J App Sci 8: 38-47.

27. Gatari MJ, Boman J, Wagner A (2009) Characterization of aerosol particles at an industrial background site in Nairobi, Kenya. X-ray Spectroscopy 38: 37-44.

28. Lee JH, Kim YP, Moon KC, Kim KH, Lee CB (2001) Fine particle measurements at two background sites in Korea between 1996 and 1997. Atmos Environ 35: 635-643.

29. Gaudichet A, Echalar F, Chatenet B, Quisefit JP, Malingre G, et al. (1995) Trace elements in tropical African savanna biomass burning aerosols. J Atmos Chem 22: 19-39.

30. World Health Organization (2003) Report on a WHO Working Group EUR/03/504268

31. Cohen DD, Garton D, Stelcer E, Hawas O, Wang T, et al. (2004) Multi-elementa analysis and characterization of fine aerosols at several key ACE-Asia sites. $J$ Geophys Res 109: D19S12.

32. Weast RC, Astle MJ (1982) Handbook of Chemistry and Physics (63 ${ }^{\text {rd }}$ Edn.) CRC. Press: Boca Raton, FL.

33. Olmez I, Sheffield AE, Gordon GE, Houck JE, Pritchett LC, et al. (1988) Compositions of particles from elected sources in Philadelphia for receptor model applications. J Air Pollut Cont Asso 38: 1392-1402.

34. Paatero P, Hopke PK (2003) Discarding or down weighting high-noise variables in factor analytic models. Anal Chimica Acta 490: 277-289.

35. Kelly JA, Jaffe DA, Baklanov A, Mahura A (1995) Heavy metals on the Kola Peninsula: aerosol size distribution. Sci Total Environ 160/161: 135-138.

36. Voutsa D, Samara C, Kouimtzis T, Ochsenkuhn K (2002) Elemental composition of airborne particulate matter in the multi-impacted urban area of Thessaloniki, Greece. Atmos Environ 36: 4453-4462.

37. Chueinta W, Hopke PK, Paatero P (2000) Investigation of sources of atmospheric aerosol at urban and sub-urban residential area in Thailand by positive matrix factorization. Atmos Environ 34: 3319-3329. 